\title{
Tahmini Öğrenme Yollarının Uygulanması Sürecinde Matematik Öğretmenlerinin Çoklu Temsil Kullanımlarının Gelişimi ${ }^{1}$
}

\section{Deniz Eroğlu'}

\author{
Dilek Tanışl1 ${ }^{3}$
}

Type/Tür:

Research/Araştırma

Received/Geliş Tarihi: April 11/

11 Nisan 2020

Accepted/Kabul Tarihi:

December 11/ 11 Aralık 2020

Page numbers/Sayfa No: 299-329

Corresponding

Author/İletişimden Sorumlu

Yazar:

deroglu@mehmetakif.edu.tr

\section{$\checkmark$ iThenticate}

This paper was checked for plagiarism using iThenticate during the preview process and before publication. / Bu çalışma ön inceleme sürecinde ve yayımlanmadan önce iThenticate yazılımı ile taranmıştır.

Copyright $@ 2017$ by Cumhuriyet University, Faculty of Education. All rights reserved.

\section{Öz}

$\mathrm{Bu}$ araştırmanın amacı, ortaokul matematik öğretmenlerinin tahmini öğrenme yol haritasına dayalı öğretimlerinde temsil kullanımlarının ve temsiller arası ilişkilendirme becerilerindeki gelişimlerinin incelenmesidir. Araştırma öğretmen gelişim deneyi olarak tasarlanmış ve sürece iki ortaokul matematik öğretmeni katılmıştır. $\mathrm{Bu}$ araştırma 10 haftada tamamlanmış ve süreç "planlama, öğretim deneyi ve durum çalışması" olmak üzere 3 farklı aşamada gerçekleştirilmiştir. Birinci aşamada öğretim programındaki kazanımlara uygun olarak, altıncı sınıfta cebir öğrenme alanında yer alan bütün kazanımları kapsayacak ve temsillerin öğretimler sırasında etkin şekilde kullanımını varsayan yol haritaları hazırlanmıştır. İkinci aşamada uzmanlardan biri iki öğretmen ile birlikte öğretim deneyini gerçekleştirmiştir. Üçüncü aşamada öğretmenler yol haritalarına göre hazırlanan öğretim etkinliklerini sınıflarında uygulamıştır. Araştırmanın verileri öğretimler sırasında ve gerçekleştirilen mesleki gelişim toplantılarında çekilmiş videolar aracılığıyla toplanmıştır. Bu araştırmanın sonucunda öğretmenlerin öğrencilerin düşüncelerinden hareketle öğrencileri temsil kullanmaya yönlendirdikleri, öğrencilerin kendi temsil biçimlerini oluşturmalarını sağladıkları ve öğrencilerin temsillere ilişkin ortaya çıkan düşüncelerini organize ederek, temsiller arası ilişki kurmada öğrencilere rehberlik ettikleri görülmüştür.

Anahtar Kelimeler: Çoklu temsiller, cebir öğretimi, öğretmen gelişim deneyi, tahmini öğrenme yol haritası, ortaokul matematik öğretmenleri.

\section{Suggested APA Citation/Önerilen APA Atıf Biçimi: \\ Eroğlu, D. \& Tanışlı, D. (2020). Tahmini öğrenme yollarının uygulanması sürecinde matematik öğretmenlerinin çoklu temsil kullanımlarının gelişimi. Cumhuriyet International Journal of Education, 10(1), 299-329. http://dx.doi.org/10.30703/cije.718210}

\footnotetext{
${ }^{1} \mathrm{Bu}$ çalışma, birinci yazarın ikinci yazar danışmanlığında hazırladığı doktora tezinden üretilmiştir ve Anadolu Üniversitesi Bilimsel Araştırma Projeleri Komisyonu tarafından kabul edilen 1406E301 nolu proje kapsamında desteklenmiştir. 2 Dr. Öğr. Üyesi, Burdur Mehmet Akif Ersoy Üniversitesi, Matematik Eğitimi, Burdur/Türkiye Assist. Prof, Burdur Mehmet Akif Ersoy University, Department of Mathematics Education, Burdur/Turkey

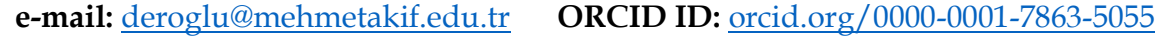

3 Prof. Dr., Anadolu Üniversitesi, Matematik Eğitimi, Eskişehir/Türkiye Prof. Dr., Anadolu University, Department of Mathematics Education, Eskişehir/Turkey

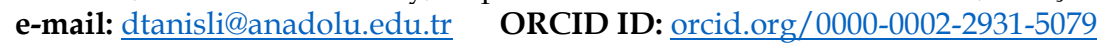




\title{
Development of Mathematics Teachers' Use of Multiple Representations throughout the Implementations of Hypothetical Learning Trajectories
}

\begin{abstract}
The purpose of the research is to examine the development of elementary mathematics teachers' use of multiple representation and translations between representations throughout the implementations of hypothetical learning trajectories. The research was designed as a teacher development experiment and two elementary school mathematics teachers participated in the process. This research was completed in 10 weeks and the process was carried out in 3 different stages as "planning, teaching experiment and case study". The first stage of the research consists of preparing hypothetical learning trajectories matching the objectives in the curriculum by covering all the objectives in algebra. All activities in HLT were appropriate to the use of representations during teaching. In the second stage, the teaching experiment was conducted with two teachers under the supervision of one of the experts. In the third stage, teachers implemented teaching activities based on HLT in their classrooms. Videos taken during teaching and at professional development meetings with teachers are the main data sources of the present research. Results reveal that teachers use students' thoughts to direct them to use representation, they allow students to create their own forms of representation, and they guide students to establish translations between representations through organizing students' emerging thoughts about representations.
\end{abstract}

Keywords: Multiple representations, algebra teaching, teacher development experiment, hypothetical learning trajectory, elementary mathematics teachers.

\section{Giriş}

Matematik öğretimi çok çeşitli ve ilişkisel boyutları olan karmaşık bir eylemdir. Bir öğretmenin etkili bir matematik öğretimi gerçekleştirebilmesi için temsil bilgisi ve temsiller arası ilişkilendirme yapabilmesi önemli görüldüğünden birçok araştırmacı matematik öğretim bilgisi içinde bu boyuta da yer vermiştir (Ball, Thames, ve Phelp, 2008; Shulman, 1986). Shulman (1986) pedagojik alan bilgisini tanımlarken, öğretmenin öğretilen kavram için gereken en kullanışlı temsil biçimleri bilmesi gerektiğini vurgulamıştır. Ball, Thames ve Phelp'in (2008) belirlemiş olduğu öğretimdeki matematiksel görevlerden ikisi temsil kullanımına yöneliktir: (1) Belirli amaçlar için temsillerin seçimi ve (2) Temsilleri temel fikirler ve diğer temsiller ile ilişkilendirme. Benzer şekilde Simon (1995) Matematik Öğretim Döngüsünün (MÖD) etkileşimlerini içeren modelinde de "öğretmenin matematiksel etkinlik ve temsillere dair bilgisi" şeklinde temsil bilgisi karşımıza çıkmaktadır. Ancak matematik öğretiminin etkili olması ve öğrenmeyi sağlaması için önemli olan öğretmenin sahip olması gereken temsil bilgisinin yanında, matematik öğretimini gerçekleştirirken bu bilgiyi uygulama şeklinin de önemli olduğu söylenebilir.

Öğretmenin öğretim içinde çeşitli temsilleri sunuyor olması, temsillerin öğrenciler tarafından anlaşıldığı ya da temsiller arasında ilişkilendirme yapıldığ anlamina gelmemektedir (Moon, Brenner, Jacob, ve Okamato, 2013). Temsiller, matematiksel fikirleri daha somut ve şeffaf kılan; bu sayede öğrenci anlayışını destekleyecek düşünceler için güçlü araçlardır (National Council of Teachers of Mathematics (NCTM), 2014). Ancak diğer bütün öğretim araçlarında olduğu gibi temsiller de dikkatle seçildiğinde ve kullanıldığında öğrencilerin düşüncelerini şekillendirdiği ifade edilmektedir (Heinze, Star, ve Verschaffel, 2009). Örneğin, aşağıda verilen şekil örüntüsünün herhangi bir adımındaki öğelerin sayısını 
hesaplamaya yarayacak açık formülün bulunmasını hedefleyen öğretim etkinliğini ele alalım.

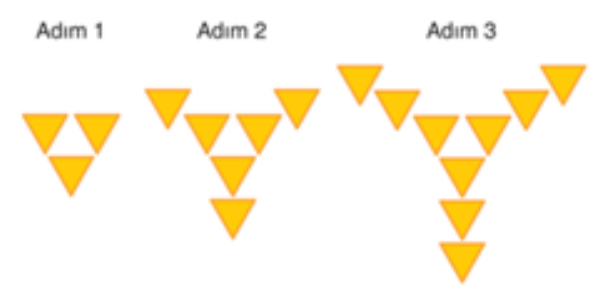

$\mathrm{Bu}$ öğretimde öğretmenin sırasıyla 4. ve 5. adımı çizdirmesi, tablo yaparak her bir adımdaki üçgen sayısını yazdırması ya da kuralın bulunmasında "ortadaki üç üçgene adım sayısının bir eksiğinin üç katı kadar üçgen eklenmesi” şeklinde bir sözel ilişki oluşturmasının ardından açık formüle ulaşması, öğretmenin öğretiminde temsilleri etkili şekilde kullandığı ya da temsiller arası ilişkilendirme yaptığı anlamı taşımamaktadır. Çünkü öğretmenlerin öğrencilere bu temsilleri kullanırken izleyecekleri yolları açık yönergeler ve kurallar vererek öğretimlerinde kullanmaları, öğrencilerin hedeflenen matematiksel fikirleri kavramsal olarak anlamalarını sinırlandırabileceği ifade edilmektedir (Stein ve Bovalino, 2001). Diğger bir ifadeyle, öğretmenin temsilleri sınıf içinde kullanmasından ziyade, öğrencilerin problemlerin çözümünde ve kavramsal öğrenimlerinde muhakeme etmelerine yardımcı bir araç olarak kendi temsil biçimlerini oluşturmaları için rehberlik etmesi gerektiği söylenebilir. Bununla birlikte, yapılan araştırmalarda matematik öğretmenleri de dâhil olmak üzere matematikte başarılı sayılan bireylerin bile, matematiksel fikirlerle ilgili temsiller arasında ilişkilendirme yapamadıkları görülmüştür (Even, 1998; Gagatsis ve Shiakalli, 2004). Dolayısıyla, öğretmenlerin sınıf içinde bahsedilen rehberliği yapabilmeleri için öncelikli olarak temsilleri kavramsal olarak öğrenmeleri ve bilgilerini öğrencileri de işin içine katarak öğretimlerine entegre edebilmeleri gerekmektedir. Bu araştırmada ortaokul matematik öğretmenlerinin tahmini öğrenme yol haritasına (TÖY) dayalı öğretimlerinde temsil kullanımlarının ve temsiller arası ilişkilendirme becerilerindeki gelişimlerinin incelenmesi amaçlanmıştır.

\section{Kavramsal Çerçeve}

$\mathrm{Bu}$ çalışmaya MÖD olarak ele alınan çerçevenin iki alt bileşeni TÖY ve öğretmen bilgisinin alt bileşeni olarak yer alan "öğretmenin matematiksel etkinlik ve temsillere dair bilgisi" temel oluşturmaktadır. TÖY Simon (1995) tarafından tanımlanan MÖD'ün ana bileşeni olarak ele alınmıştır. MÖD ise en sade haliyle "Öğrenci Bilgisini Değerlendirme, Öğretmen Bilgisi ve TÖY olmak üzere üç bileşenden oluşmaktadır. TÖY, öğrenme ile öğretme arasında köprü kuran yapılandırmacı öğretim modellerinden biri olarak görülmektedir (Simon, 1995; 2014). Simon (1995), TÖY'ü "öğrenmenin ilerleyebileceği yola ilişkin öğretmenin tahmini” olarak ifade etmiştir. TÖY'ün oluşumunda üç bileşen göz önünde bulundurulur: 1. Öğrenme hedefleri, 2. Öğrenimi destekleyecek etkinlikler ve 3. Öğrenmenin nasıl gerçekleşeceğine dair hipotezler (Simon, 1995). Bu model içinde, MÖD için belirlenmiş olan üç ana bileşen de alt bileşenlere ayırılarak öğretmen bilgisi içerisinde "öğretmenin matematiksel etkinlik ve temsillere dair bilgisi"ne yer verilmiş ve MÖD içinde belirlenmiş olan bütün bileşenlerin birbirleriyle çift yönlü ilişkisinin olduğu ifade edilmiştir. p

Matematik eğitiminde temsillerin kullanımının önemi birçok araştırmacı tarafından vurgulanmaktadir (Even, 1990; Lesh, Post ve Behr, 1987; NCTM, 2014). Lesh, Post ve 
Behr (1987) matematik eğitiminde beş farklı temsil biçimi tanımlamaktadır: gerçek yaşam temsili, somut temsil, aritmetik-sembol gösterimi, sözel temsil ve resim-grafik temsili. Bunun yanında Lesh ve arkadaşları (1987) bu temsil biçimlerinin problem çözme sürecinde dönüşümlerine ilişkin üç adım önermiştir. İlk adım sözel temsilin matematiksel desene çevrilmesi, ikinci adım matematiksel desenin aritmetik ya da sembolik ifade edilmesi ve son olarak sözel açılamanın yapılmasıdır. Lesh son adım olmadan, öğretmenlerin belirli bir öğrencinin problem çözme sürecini yanlış anlayıp anlamadığını tam olarak belirleyemeyeceğini ifade etmektedir. Bununla birlikte, Ainsworth (1999) çoğu öğrencinin farklı temsil türleri arasındaki bağlantıların önemini anlamadıklarını ifade etmektedir. Her ne kadar öğrencilerin bir kavrama ait bütün temsilleri bilmesi ve anlaması gerekmezken, öğretmenin farklı temsil çeşitlerini anlaması, kullanabilmesi, bu temsiller arasında gereken ilişkileri ve dönüşümleri gerçekleştirebilmesi gerektiği ifade edilmiştir (Even, 1990). Nitekim öğretmenlerin, sınıfta çoklu temsilleri kullanan öğrencileri teşvik ederek öğrenme performansını arttırmak için farklı öğretim stratejileri benimsemelerinin daha iyi olabileceği belirtilmiştir (Cai ve Hwang, 2002).

Simon'un (1995) oluşturmuş olduğu ilişkisel çerçeve olan MÖD kullanılarak bu araştırma da TÖY'leri tasarlanarak, bu yol haritasının uygulanması sürecinde öğretmenin temsil kullanımları geliştirilmeye çalışılmıştır. TÖY'lerinin geliştirilmesi süreci hedeflerin belirlenmesinin ardından öğrencilerin öğrenme ilerleyişlerinin nasıl gerçekleştirileceğine ilişkin hipotezlere dayanmakta ve bu hipotezler doğrultusunda öğretim etkinlikleri geliştirilmektedir. Bu kavramsal yapının uygulanması sürecinde ise öğretmenlerin temsil bilgilerini kullanmaları, uygulamaları ve yapacakları uygulamalar sonucunda edindikleri deneyimlerle bu bilgiyi geliştirmeleri beklenmiştir. TÖY için planlanmış öğretim etkinliklerinin uygulanması sırasında, öğretmenlerden beklenilen iki durum bulunmaktadır:

- $\quad$ Etkinlikler sürecinde öğrencilerin düşüncelerinden hareketle temsillerin (tablo, cebirsel ifade, sözel durum) kullanımı için öğrencileri yönlendirmek ve öğrencilerin kendi temsil biçimlerini oluşturmalarını sağlamak,

- $\quad$ Öğrencilerin temsillere ilişkin ortaya çıkan düşüncelerini organize ederek, temsiller arası ilişki kurmada öğrencilere rehberlik etmektir.

\section{İlgili Alan-yazın ve Araştırmanın Gerekçesi}

Türkiye'deki matematik eğitimi alanında temsiller üzerine çeşitli araştırmaların gerçekleştirildiği görülmektedir: (1) Ortaokul ve lise öğrencilerinin temsil kullanımları (Bulut, Aygün ve İpek, 2018; Yıldırım ve Albayrak, 2016), (2) Matematik ve sınıf öğretmen adaylarının temsil kullanımları (Çelik ve Sağlam-Arslan, 2012; Dündar ve Y1lmaz, 2015; İpek ve Okumuş, 2012) , (3) Matematik öğretmenlerinin temsil kullanımları (Eroğlu ve Tanışlı, 2015; Tataroğlu-Taşdan ve Çelik, 2015), (4) Farklı disiplinlerde temsil kullanımları (Yayla ve Özsevgeç, 2015) ve (5) Temsillerin ders kitaplarındaki yeri (İncikabı, 2017; İncikabı ve Biber, 2018). Bu araştırmaların büyük çoğunluğu öğrencilerin ne tür temsilleri kullandıklarının, öğretim içinde kullanılan temsillerin öğrencilerin başarısı üzerindeki etkisi ve temsiler arası geçiş becerilerinin incelenmesi için gerçekleştirilmiştir. Hiç şüphesiz öğrencilerin ve öğretmen adaylarının ya da öğretmenlerin temsil bilgileri, böyle etkili bir aracın bireyler tarafından nasıl anlaşıldı ̆̆ı konusunda bilgi vermesi açısından değerlidir. Öte yandan, temsil kullanımının öğrenci başarısı üzerindeki etkilerine yönelik araştırmalarda 
temsilin öğretim içerisinde kullanılması gerekliliğini ortaya koymaktadır. Özellikle, çok sayıda öğretmen adayı ile gerçekleştirilen araştırmalarda, gelecekte öğretmen olacak adayların temsil bilgilerini ortaya koymak ve öğretmenlik mesleğine atılmadan önce gerekli tedbirleri almak önem arz etmektedir. Ancak öğretmenlerin öğretim içinde matematiksel temsilleri nasıl kullandıkları ve bu kullanımlarının gelişimleri gerçekte öğrencileri başarıya ulaştırmak adına önem arz etmektedir. Eroğlu ve Tanışlı (2015) ortaokul matematik öğretmenlerinin öğrencilerin hatalı temsil içeren yanıtlarını nasıl yorumladıklarını ve bu hatalı yanıtlar için hangi öğretim stratejilerini önerdiklerini inceledikleri araştırmalarında, öğretmenlerin öğrenci hatalarını yorumlamada yetersiz kaldıklarını ve buna bağlı olarak da önerdikleri stratejilerin çeşitliliğinin az olduğu ortaya çıkarmıştır. Öte yandan, temsil bilgisinin analizinden ziyade, öğretmenlerin temsil kullanımlarını sınıf içinde inceleyen ve öğretim içinde temsil kullanımının gelişimini amaçlayan Tataroğlu-Taşdan ve Çelik'in (2015) yapmış olduğu araştırma, öğretmenlerin aldıkları eğitim sonucunda temsil bilgilerinin geliştiği sonucuna ulaşmıştır.

Matematiksel temsillerin etkili bir öğretim için gerekliliğine ilişkin vurgular (Common Core State Standards (CCSS-M), 2015) ve ulusal alan-yazın incelemesi bu araştırmanın yapılması için çeşitli gerekçeler oluşturmaktadır. Bunlardan ilki alanyazında ortaokul matematik öğretmenlerinin temsil bilgilerini (Eroğlu ve Tanışlı, 2015) ve bunların öğretim içinde kullanımlarını (Tataroğlu-Taşdan ve Çelik, 2015) inceleyen az sayıda araştırma bulunmaktadır. Dolayısıyla, matematik öğretmenlerinin temsil kullanımlarının incelenmesine yönelik alan-yazında bir boşluğun varlığından söz edilebilir. Oysa birçok araştırmacı sınıf içinde etkili temsil kullanımının öğretimdeki öneminin ve kritik rolünün altını çizmektedir (Mitchell, Charalambous, ve Hill, 2014). Bu da matematik öğretmenlerinin sınıf içindeki temsil kullanımına yönelik araştırma yapılması gerekliliğini ortaya çıkarmaktadır. Bu araştırmada da öğretmenlerin temsilleri ve temsiller arası geçişi sınıf ortamına nasıl entegre ettikleri incelendiğinden, alan-yazındaki öğretmenlerin temsil kullanımına yönelik araştırma yapılması gerekliliğine ilişkin boşluğu doldurması bakımından önemli görülmektedir. Gerçekleştirilmiş olan bu araştırma aynı zamanda bir mesleki gelişim çalışmasıdır ve öğretmenlerin sınıf içi uygulamalarının nasıl geliştirilebileceğine dair bilgiler sunmaktadır. Öğretmenlere yönelik mesleki gelişim programları, büyük ölçüde öğretmenlerin mesleki bilgisini arttırmayı, sınıf uygulamalarını geliştirmeyi ve en sonunda öğrencinin öğrenimini garantilemeyi amaçlamaktadır (Fishman, Marx, Best, ve Tal, 2003). Türkiye'de öğretmenler ile gerçekleştirilen çalışmalar öğretmenlerin ya da sıklıkla ögrretmen adaylarının pedagojik alan bilgilerinin, matematik alan bilgilerinin, öğrenci bilgilerinin, öğretim programı bilgilerinin ve öğretim stratejileri bilgilerinin görüşme, döküman incelemesi ya da gözlemler yoluyla ortaya konulması şeklinde tespitlere dayanmaktadır (Gökkurt ve Soylu, 2016; Tanışlı, 2013; Türnüklü, 2005). Öte yandan, PAB'nin gelişimi üzerine yapılmış olan çalışmaların çoğunluğunun ise öğretmen adaylarının öğretmen yetiştirme eğitimleri sırasında alan derslerinde kazandıkları ya da geliştirdikleri bilgiye yönelik gerçekleştirildiği tespit edilmiştir (Şimşek ve Boz, 2016). Dolayısıyla temsillerle ilgili çalışmaların yanında öğretmenlerle yapılan çalışmaların azlığı ve bu çalışmaların sadece teşhisle sınırlı kalması bir yana, hizmet içi ve öğretmen yetiştirme programlarındaki eksikliklerde göz önünde bulundurulduğunda, öğretmenlerle yapılacak ve öğretmenlerin sınıf içinde 
öğretimlerinin incelendiği araştırmalar konusunda bir boşluğun olduğu göze çarpmaktadır. Matematik öğretmenlerinin gelişimi üzerine yapılan birçok araştırma matematik öğretmenlerinin kendi deneyimleri yoluyla ve kendi sinıflarında öğrendiklerini ortaya koymuştur (Leikin, 2006; Nathan ve Knuth, 2003). Bu araştırma öğretmenlerin temsilleri ve temsiller arası geçişi sınıf ortamına entegrasyonunun gelişimine yönelik olduğundan ve öğretmenlerin kendi deneyimlerinden yola çıkarak sınıf ortamında öğrenmelerini sağladığından dolayı önemli görülmektedir. Ayrıca bu araştırmanın bahsedilen konuyla ilişkili alan-yazındaki boşluğu doldurur nitelikte olduğu söylenebilir.

Son olarak öğrencilerin merkeze alınması ve düşüncelerinin anlaşılarak öğretimlere adapte edilmesinin ön plana çıtığ1 günümüzde TÖY gibi öğrencinin düşüncesiyle öğretimi ilişkilendiren yollar ilgi çekmeye başlamıştır (Simon, 2006). Öğretmenlerin TÖY'e dayalı bir öğretimi nasıl gerçekleştireceği ve öğrenci düşüncesini ön plana alan öğretimlerin gerçekleştirilmesi için öğretmenlerin kendi sınıflarındaki öğretimlerinden nasıl öğrenecekleri yeni araştırılan bir konu olduğundan henüz çok az şey bilinmekte ve bu yönde araştırmalara ihtiyaç duyulmaktadır (Eroğlu, Camci ve Tanışlı, 2019). Bu araştırmada da öğretmenlerin TÖY'e dayalı tasarlanmış öğretimlerinde kullanacakları temsillerin öğrenci düşüncesinden hareketle öğretime nasıl entegre edileceğine dair sorulara yantlar aranmış ve öğretmenlerin öğrencilerin düşüncelerinden hareketle temsillerin kullanımı için öğrencileri nasıl yönlendireceğine ve öğrencilerin temsillere ilişkin ortaya çıkan düşüncelerini organize ederek, temsiller arası ilişki kurmada öğrencilere nasıl rehberlik edebileceğine dair öğretimleri geliştirilmeye çalışılmıştır. Bu gelişimin hangi mesleki gelişim uygulamalarıyla gerçekleştirilebileceği ve öğretmenlerin TÖY'e dayalı öğretimlerinde temsilleri nasıl kullanabileceklerine dair bilgi sunması açısından da gerçekleştirilen bu araştırma önemli görülmektedir. Bahsedilen bu gerekliliklerden hareketle bu araştırmada “Ortaokul matematik öğretmeninin TÖY'e uygun olarak tasarlanmış öğretim sürecinde temsilleri kullanımları ve temsiller arası ilişkilendirme yolları nasıl değişmiştir?" sorusuna yanıt aranmıştır.

\section{Yöntem}

$\mathrm{Bu}$ araştırma, iki ortaokul matematik öğretmeninin altıncı sınıf cebir öğrenme alanı için hazırlanmış TÖY'lerine dayalı öğretimlerinde kullandıkları çoklu temsillerin kullanımını geliştirmek üzere tasarlanmış bir öğretmen gelişim deneyidir. Öğretmen gelişim deneyinde, konuyla ilişkili uzman araştırmacı bir ekibin, sürekli analiz ve müdahale döngüsünün bir parçası olarak öğretmenlerin mesleki gelişimi çalışılmakta ve araştırılmaktadır (Simon, 2000). Öğretmen gelişim deneyi, (1) öğretim deneyi ve (2) durum çalışması yöntemlerinin birlikte kullanıldığı bir araştırma yöntemi ve öğretmen gelişim modelidir. Bu araştırma kapsamında, öğretim deneyinin bir parçası olarak öğretmenlerin cebir öğretimine dair pedagojik ve çoklu temsiller konusundaki bilgilerini geliştirmek amacıyla araştırmacı iki öğretmenin katıldığı dersler düzenlemiştir. Bu dersler öncesinde, araştırmanın başlangıcında öğretmenlerin altıncı sınıf cebir öğretim bilgilerini değerlendirmek amacıyla yarı-yapılandırılmış görüşmeler yapılmış ve gerçekleştirilen derslerde öğretmenlerin eksik oldukları noktalara odaklanılmıştır. Her bir derste gerçekleştirilen etkinlikler aracılığıyla (problem çözme, video analizi ve ders planlama gibi) öğretmen gelişimi desteklenmiş ve sürekli analizler yardımıla her bir dersin sonrasındaki ders oturumlarının 
planlaması gerçekleştirilmiştir. Öte yandan, durum çalışmaları sürecinde ise öğretmenlerin bireysel olarak sınıf içindeki öğretimleri incelenmiş ve öğretim deneyi kapsamında öğretmenlerin bireysel gelişimlerinin sosyal ortamlarda (yani kendi sınıf içi öğretimlerinde) nasıl gerçekleştirildiği araştırılmıştır. Bu çalışmayı yapan araştırmacılar, doktora sürecinde cebir öğretimine yönelik dersler almış, aynı konuya yönelik dersler vermiş ve bu alanda çeşitli sınıf içi uygulama ve mesleki gelişim çalışmaları gerçekleştirmiştir. Dolayısıyla, ortaokulda cebir öğretimine yönelik öğretmenleri destekleyecek yeterliliğe sahiptir. Bu çalışma kapsamında da araştırmacı, öğretmenlerin sınıf içinde kendilerini geliştirmek için klinik danışman ve öğretmenlere ders içindeki öğretimlerine destek olacak kaynak rolünü üstlenmiştir.

\section{Katılımcilar}

Bu araştırma, 2017-2018 öğretim yılında İç Anadolu Bölgesinde yer alan bir şehirdeki farklı ortaokullarda görev yapan iki matematik öğretmeni ile gerçekleştirilmiştir. Araştırmaya katılan öğretmenler kolay ulaşılabilir durum örneklemesi ile belirlenmiştir. Araştırma süreci zaman ve çaba gerektirdiğinden, haftalık öğretim deneyi kapsamında gerçekleştirilebilecek derslere katılabilecek ve kendi mesleki gelişimine açık öğretmenler gönüllük esasına dayalı olarak seçilmiştir. Öğretmenlerin isimleri Damla ve Emre olarak kodlanmıştır. Araştırmadaki öğretmenlerden biri il merkezinde, diğeri ise ilçede yer alan bir ortaokulda görev yapmaktadır. Araştırmaya katılan öğretmenlerin her ikisi de ilköğretim matematik öğretmenliği lisans programı mezunudur. Araştırma sürecinde iken her iki öğretmen de matematik eğitimi yüksek lisans programı öğrencisiyken, mesleklerinin dördüncü yıllarını çalışmış ve ilk üç yıl boyunca altıncı sınıfta öğretim gerçekleştirmiştir.

\section{Verilerin Toplanması}

$\mathrm{Bu}$ araştırmada, öğretmenlerin öğretimleri içindeki temsil kullanımlarındaki gelişimini ortaya koymak amacıyla iki farklı veriden yararlanılmıştır: (1) öğretmenlerin öğretimleri sırasında çekilmiş ders videoları, (2) öğretmenler ile gerçekleştirilen mesleki gelişim toplantılarında çekilmiş videolar. Öğretmenlerin öğretimleri sırasında toplam 64 ders saati, mesleki gelişim toplantılarında ise toplam 40 saat video kaydı alınmıştır. Bu kayıtların tamamı öğretim deneyi sırasında planlanan öğretim etkinliklerinin uygulanması ve durum çalışmasında uygulaması gerçekleştirilen sınıf içi uygulamalar sırasında çekilmiştir. Çekilen sınıf için uygulama videoların tamamında öğretmenler altıncı sınıf cebir öğrenme alanında temsil kullanımının yer aldığı öğretimler gerçekleştirmiştir. Durum çalışması sürecinde ders videoları araştırmanın öğretmenlerin gelişimlerini göstermek için ana veri kaynağ olarak kullanılmıştır. Öğretim deneyleri sürecinde ise gerçekleştirilen mesleki gelişim toplantılarının tamamı video kamera ile kayıt altına alınmış ve öğretmenlerin öğretimlerindeki gelişimin nasıl gerçekleştiğini açıklamak için kullanılmıştır. Ayrıca bu videolar, öğretmenlerin öğretimlerinin analizi gerçekleştirilirken, öğretmenlerin temsil kullanım ve temsiller arası ilişkilendirme etkinliklerini yorumlamada yardımcı olmuştur.

İşlem

Öğretmenlerin TÖY'lerine dayalı öğretimlerinde kullandıkları çoklu temsillerin kullanımını geliştirmek üzere tasarlanmış bu araştırma 10 haftada tamamlanmış bir öğretmen gelişim deneyidir (Simon, 2000). 


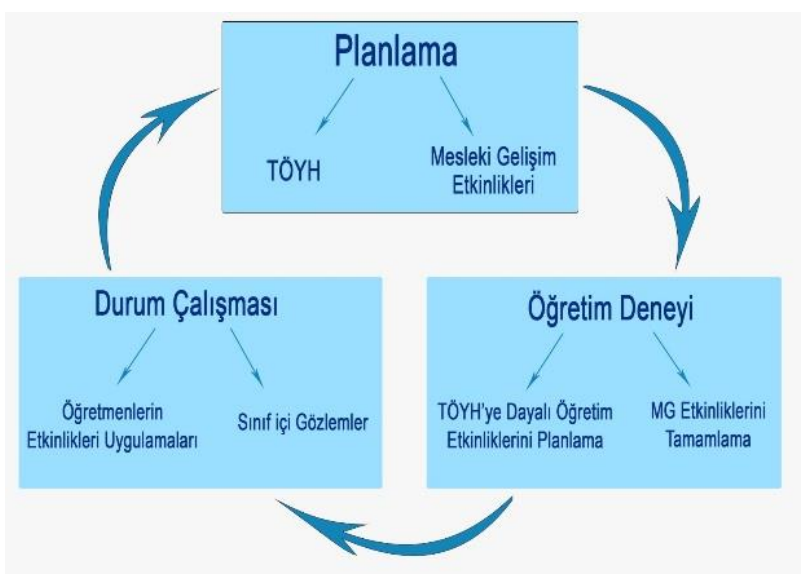

Şekil 1. Öğretmen Gelişim Deneyi

Araştırma Şekil 1'de görüldüğü üzere 3 farklı aşamada döngüsel şekilde yürütülmüştür. Birinci aşamada konuyla ilişkili üç uzman araştırmacı ekiple birlikte öğretim programındaki kazanımlara uygun olarak, altıncı sınıfta cebir öğrenme alanında yer alan bütün kazanımları kapsayacak ve temsillerin öğretimler sırasında etkin şekilde kullanımını varsayan TÖY hazırlanmıştır. Bu uzman ekiple ayrıca öğretmenlerle her bir hafta gerçekleştirilecek öğretim deneyleri için mesleki gelişim etkinlikleri hazırlanmıştır. Mesleki gelişim etkinlikleri öğretmenlerin sınıflarında çekilen öğretim videolarının çeşitli bölümleri ile bu bölümlerin tartışılması için gereken tartışma sorularından oluşmaktadır. Her bir haftanın sonunda öğretim videolarında belirlenen kritik olaylar tespit edilmiş, öğretmenlerin temsil kullanımı konusunda nasıl gelişeceklerine yönelik tartışma soruları oluşturulmuştur. İkinci aşamada uzmanlardan biri iki öğretmen ile birlikte öğretim deneyini gerçekleştirmiştir. Bu süreçte hazırlanan mesleki gelişim etkinlikleri öğretmenler ile gerçekleştirilmiştir. Mesleki gelişim etkinliğinin ardından TÖY öğretmenlerin de görüşleriyle son haline getirilerek, yol haritasına uygun öğretim etkinlikleri tasarlanmıştır. Ayrıca, bu etkinliklerin öğretimi sürecinde temsillerin ve temsiller arası geçişlerin nasıl uygulanacağı tartışlarak öğretim deneyi sonuçlandırılmıştır. Gerçekleştirilen öğretim deneyi alanda konuyla ilgili araştırmaları olan ve öğretmenlerin mesleki gelişimlerini çalışan makalenin yazarı iki matematik eğitimcisi akademisyen tarafından, akademisyenlerin çalıştığı kurumda yer alan bir sınıfta her iki öğretmenin eş zamanlı katılımıyla gerçekleştirilmiştir. Öğretmenlere uygulanan mesleki gelişim etkinlikleri Tablo.1'de yer almaktadır. Üçüncü aşamada öğretmenler TÖY'e dayalı hazırlanan öğretim etkinliklerini sınıflarında uygulamıştır. Öğretmenler bu aşamanın ilk beş haftasında 5 ders saati, son dört haftasında 2 ders saati öğretim gerçekleştirmişlerdir. Araştırmacılardan biri uygulanan bütün dersleri gözlemlemiş ve video kamera ile kayıt altına almışır. Araştırmacı dersler sırasında önemli gördüğü noktaları alan notu olarak kaydetmiş, sonrasında notlarından yararlanarak videolarda önemli bölümleri tespit etmiş ve uzman görüşmesi için öğretmenlerin öğretimlerine temsilleri nasıl entegre ettikleri incelenmiştir. Bu döngünün son aşamasıdır. Bundan sonra yeniden birinci aşamaya dönülmüş ve aynı döngü 9 hafta boyunca tekrarlanmıştır. Beş haftalık süreç altıncı sınıf cebir öğrenme alanında yer alan kazanımların öğretiminde, TÖY'lerdeki temsillerin kullanımına yönelik olarak 
planlanmıştır. Son dört haftada ise ilk haftalardaki etkinliklere benzer etkinlikler gerçekleştirilmiş ve öğretmenlerin öğretimlerine temsillerin kullanımını entegre etme süreçleri araştırmanın hedefleri doğrultusunda geliştirilmiştir.

Tablo 1

Gerçekleştirilen Mesleki Gelişim Etkinlikleri

\begin{tabular}{|c|c|c|c|}
\hline Hafta & Etkinlikler & Hafta & $\begin{array}{l}\text { Etkinlikler } \\
\end{array}$ \\
\hline 1 & $\begin{array}{c}\text { Problem çözme } \\
\text { Problemlerin Uygulama Süreci } \\
\text { hakkında tartışma } \\
\text { MÖD ile ilgili kuramsal çalışma }\end{array}$ & 4 & $\begin{array}{c}\text { Öğrenci görüşmelerinin analizi } \\
\text { Öğretim değerlendirmesi } \\
\text { Örnek ders senaryosunun incelenmesi }\end{array}$ \\
\hline \multirow[t]{2}{*}{$2-3$} & \multirow{2}{*}{$\begin{array}{l}\text { Sınıf içi durum analizi } \\
\text { Öğretim değerlendirmesi }\end{array}$} & 5 & $\begin{array}{l}\text { Öğretim değerlendirilmesi } \\
\text { Örnek ders videosu izleme } \\
\text { Örnek öğrenci görüşmesi inceleme }\end{array}$ \\
\hline & & $6-9$ & $\begin{array}{l}\text { Öğretim değerlendirmesi } \\
\text { Öğrenci görüsmelerinin analizi }\end{array}$ \\
\hline 10 & $\begin{array}{c}\text { Öğretmen gelişimlerinin } \\
\text { değerlendirilmesi }\end{array}$ & & \\
\hline
\end{tabular}

\section{Verilerin Analizi}

$\mathrm{Bu}$ araştırmada durum çalışmasında çekilen 64 ders saati ve öğretim deneylerinde çekilen 40 saat video kaydının analizi gerçekleştirilmiştir. Verilerin analizinde Powell, Francisco ve Maher' in (2003) tanımladığı, (1) Video verilerinin dikkatlice izlenmesi, (2) Video verilerinin tanımlanması, (3) Kritik olayların tanımlanması, (4) Döküm yapılması, (5) Kodlama, (6) Olay örgüsünün oluşturulması ve (7) Hikayeleştirme aşamalarından oluşan yöntem kullanılmıştır. Bu yöntemde tanımlanan ilk üç adım araştırma sürerken gerçekleştirilmiştir.

Öğretmenlerin gelişimlerini gösterebilmek için ana veri kaynağı olarak kullanılmış ders videoları araştırma sürecinde her hafta izlenmiş ve araştırma ile ilgili olan video bölümleri veri olarak tanımlanmıştır. Araştırma verilerinin tanımlanmasının ardından dersler sırasında öğretmenlerin temsil kullanımıyla ilgili olan bölümler kritik olay olarak belirlenmiş ve geçerlilik komitesine sunulmuştur. Geçerlilik komitesi, bu araştırmayı düzenli olarak takip eden, matematik eğitimi alanında doçentliğini almış ve mesleki gelişim çalışmaları gerçekleştiren 2 farklı araştırmacıdan oluşmaktadır. Bu videoların seçilen bölümleri öğretmen gelişimini ortaya koymak için analiz edilen veri kaynaklarını oluşturmaktadır.

Öğretmen gelişim deneyinde üç aşamadan oluşan sürecin bitiminin ardından veri olarak tanımlanan videolar yeniden izlenmiş ve geçerlik komitesi tarafından onaylanan bölümlerin dökümü gerçekleştirilmiştir. Bu dökümler Tablo 2' de görüldüğü üzere diyaloglar, diyaloglara yapılan açıklamalar ve fotoğraflardan oluşmaktadır. Dökümlerin tamamlanmasının ardından kodlama bölümüne geçilmiştir. İki farklı araştırmacı birlikte çalışarak belirlenen bölümlere kodlar atamış ve kod listesinde yer alan ifadeler birbirini tekrar edene kadar devam etmiştir. Örneğin öğretmen şekil örüntüsü içeren bir örüntü probleminde öğrencilerde şeklin yapısına yönelik fikri şekil üzerinde kullanmamışsa, bu duruma "temsilleri ilişkilendirmede öğrenciye rehberlik etmeme" şeklinde bir kod atanmıştır. Ardından kod listesi kullanılarak araştırmacılar verilerin bir kısmını bağımsız olarak kodlamış ve kodlamaları karşılaştırmak için bir araya gelmiştir. Bu bağımsız kodlama araştırmanın 
inandırıcılığını artırmak için gerçekleştirilmiştir (Patton, 2014). Araştırmacılar bölümlere atadıkları kodları karşılaştırmış ve bir fikir birliğine varıldıktan sonra, bu çalışmadaki birinci yazar kodlamaların tamamını gerçekleştirmiştir. Aşağıda kodlamaların nasıl gerçekleştirildiğine ilişkin bir örnek yer almaktadır.

Tablo 2

Örnek Veri Analizi

\begin{tabular}{|c|c|c|}
\hline & Veri olarak tanımlanan diyaloglar & Veri olarak tanımlanan fotoğraflar \\
\hline 75 & Öğretmen: Peki Mehmet arkadaşınız 31 diyor. Peki soruyorum 31'i nasıl buldun? 31 tane & \\
\hline 76 & olduğunu nasil buldun? & \\
\hline 77 & Öğrenci: Bir karede 4 tane var. Öbürleri üçer üçer gidiyor, 9 tane 3 var öğretmenim. Bir de & \\
\hline 78 & $4 \mathrm{var}$, topladım 31. & \\
\hline 79 & Öğretmen: Peki tamam otur bakalım doğru m?... Başka fikri olan? & \\
\hline 80 & Öğrenci: Benim sonucumda aynı 5 taneyi bulduk. 5 tanesi 16 çıktı. Mesela öğretmenim & Mahmet - \\
\hline 81 & yukarda hep dört kenar olacak öğretmenim. íkide bir tane kürdan eksik oluyor. O & forkon $\rightarrow$ \\
\hline 82 & yüzden 16.16 ile toplarız, bir kenarda iki tane kürdan olmuş olacak. & \\
\hline
\end{tabular}
sembolik temsili tahtaya yazmıştır.

KOD: Öğrenci düşüncesini sorgulama (Şekil)

136 Öğretmen: Şimdi birinci adımda kaç kürdan var 4. Şöyle bir şey olabilir şunun sabit

137 kaldığını düşünelim. Şu bir tane sabit değil mi? (Tahtada şekil üzerinde bir tane sabit

138 gösterdi.) Kaç tane ekliyoruz? 3. Peki burada biz kaç ekliyoruz? 3. Peki burada kaç

139 ekliyoruz? 3. Demek ki hep 3 ekliyoruz. Birinci adımda normalde ben kaç ekliyorum? 3.

140 bir artı üç (1+3 yazdı.). İkinci adımda kaç oldu toplam? 7. Aslında ne oldu? Bir artı üç artı üç.

$141 \quad(1+3+3$ yazdı)...

Açıklama: Öğretmen şekil temsilini öğrencilere açıklayarak, yanda yer alan tablo temsilini oluşturdu.

KOD: Kendi düşüncelerini ön plana çıkarma

KOD: Temsil oluşturmada öğrenciye rehberlik etmeme (Sembolik)

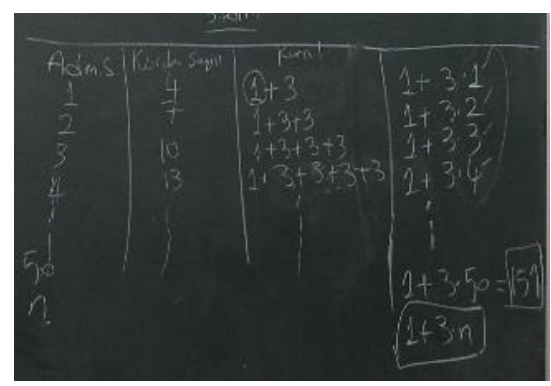

KOD: Temsil oluşturmada ö̆grenciye rehberlik etmeme (Tablo)

Bütün verilerin kodlanmasının ardından öğretmenlerin gelişimini ortaya koymak için bir olay örgüsü oluşturulmuştur. Bu olay örgüsünün oluşturulmasında öğretmenlerin temsil kullanımlarında gelişimini göstermek amacıyla 9 haftalık durum çalışması sürecinde cebir öğrenme alanı içinde öğretimi gerçekleştirilen 17 etkinliğe odaklanılmıştır. Bu etkinliklerin tamamı öğretmenlerin sözel durum, şekil, tablo ve cebirsel ifade olmak üzere dört farklı temsil çeşidini kullanabilmeleri için gereken bağlama sahiptir. Bu etkinliklerde öğretmenlerin gelişimlerinde şu boyutlara odaklanılmıştır: 1. Öğrencilerin düşüncelerinden hareketle temsillerin (şekil, tablo, cebirsel ifade, sözel durum) kullanımı için öğrencileri yönlendirme durumları. 2. Öğrencilerin kendi temsil biçimlerini oluşturmalarını sağlamaları. 3. Öğrencilerin temsillere ilişkin ortaya çıkan düşüncelerini organize etme durumları. 4. Temsiller arası ilişki kurmada öğrencilere rehberlik etme durumları. Odaklanılan boyutlar araştırma sürecinde öğretim deneylerinde, haftalık gerçekleştirilen video analizlerinde öğretmenlerin temsillerin kullanımında tanımlanan zorluklardan oluşmaktadır. Bu gelişimi sunmak için bulgular bölümü Damla Öğretmen' in gelişimi ile Emre Öğretmen'in gelişimi ayrı ayrı, öğretmenlerin başlangıçtaki temsil 
kullanımları ile geliştirmiş oldukları temsil kullanımları iki farklı başlık altında hikayeleştirilmiştir.

\section{Bulgular}

$\mathrm{Bu}$ araştırmada altıncı sınıf cebir öğrenme alanı için hazırlanmış TÖY'lerine dayalı etkinliklerin öğretimleri sürecinde öğretmenlerin temsil kullanımlarındaki gelişimleri ortaya konulmuştur. TÖY'lerinin öğretimleri öğrenci düşünceleri üzerine kurulu olduğundan, öğretmenlerin öğrencilerin temsil üzerine düşüncelerini öğretimlerine nasıl entegre ettikleri ve bu düşünceler üzerinden derslerini nasıl yönlendirdiklerine yönelik toplamda 17 etkinliğin öğretiminden elde edilen bulgular bu bölümde sunulmuştur. Bulgular Damla ve Emre öğretmen için oluşturulan iki başlık altında ayrı olarak ele alınmıştır. İlk başlık öğretmenlerin başlangıçtaki temsil kullanımlarını açıklamaktadır. Bu başlığın altında öğretmenlerin öğretimlerinde eksiklik olarak ortaya çıkan temsil kullanımlarına yer verilmiştir. İkinci başlık olan gelişimin ardından temsil kullanımları altında ise öğretmenlerin başlangıçta eksik olarak nitelendirilen temsil kullanımlarının dönüşümünün sınıf içine yansımaları açıklanmıştır.

\section{Damla Öğretmen'in Başlangıçtaki Temsil Kullanımı}

Damla Öğretmen'in başlangıç olarak ele alınan temsil kullanımında, temsiller arası ilişkilendirme yapmadığı ve öğrencilerin temsiller konusunda ortaya çıan düşüncelerini derslerine entegre etmediği görülmüştür. Damla Öğretmen'in öğrencilerin temsiller konusunda ortaya çıkan ilişkisel düşüncelerini derslerine entegre etmemesine bir örnek Tablo 3'te gösterilen örüntü probleminin çözümü sırasında yaşanmıştır. Bu diyalogda öğrencinin şeklin yapısını adım sayısı ile ilişkilendirerek açıkladığı ve bunu da bir kural olarak ifade ettiği görülmektedir. Bu noktada problemin çözümünde öğrencilerin çözüme ilişkin bir fikri olduğu ve bu fikri ortaya çıkardığı söylenebilir. Bu durum TÖY'de öğrenci düşüncelerinin kullanılması noktasında bir fırsat oluşturmaktadır. Ancak öğretmen öğrencinin şekil temsili ile yarı sembolik temsili (sembolik temsile ilişkin sözel ifadesi) arasındaki ilişkiye yönelik düşüncesini diğer öğrenciler için görünür kılmak ve dersin içinde kullanmak yerine kendisi yeni bir yol ile çözüme devam etmiştir. Öğretmenin bundan sonraki yolu Tablo 3 'te yer alan ikinci diyalogda görülmektedir. Öğretmen öğrencinin ortaya atmış olduğu düşünceyi şekil ve sembolik temsil ile ilişkilendirmesi için rehberlik etmek yerine kendi düşüncesini ön plana çıkarmış ve yeni bir yol açıklayarak sembolik temsili ifade etmiştir. Öğretmen burada kendi istediği şekilde ilerlettiği ve cebirsel kuralını yazdırdığı etkinliğin sonunda öğrencinin şeklin yapısına ilişkin bulmuş olduğu yolu da cebirsel olarak ifade etmek istemiştir. Ancak öğrencilerin yanıtları arasında ya da bu yanıtların şekil ve tablo temsiliyle ilişkisini kurmalarını sağlayacak sorgulamayı gerçekleştirmediği için öğrencilerden yanıt alamamış, dolayısıyla öğrencilerin bulmuş olduğu yolun kuralını yazdırmaktan vazgeçmiştir. 
Tablo 3

Ders İçinde Yaşanan Diyaloglar

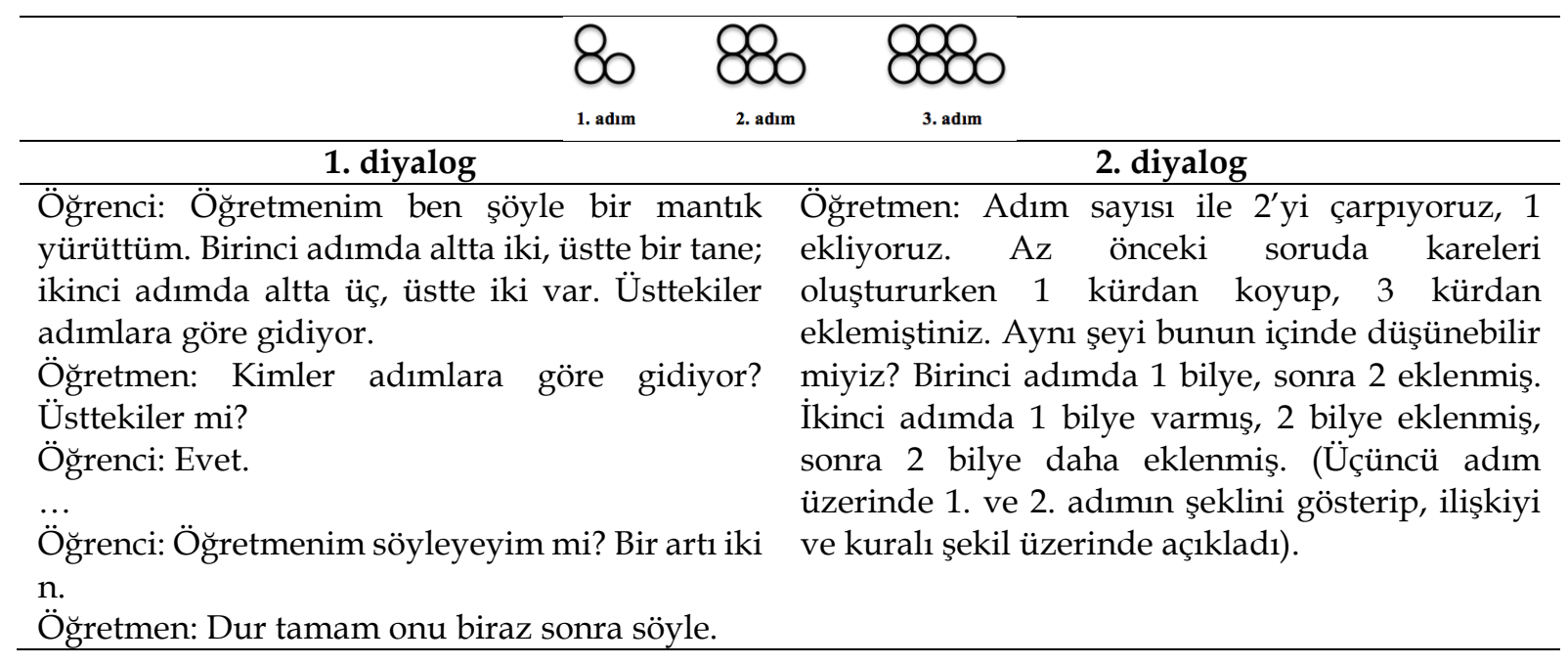

Temsiller arası ilişkilerin kurulamadığı ve öğrencilerin temsiller konusunda ortaya çıkan ilişkisel düşüncelerini derslerine entegre edemediği bir başka durumda da Tablo $4^{\prime}$ te verilen diyalog ortaya çıkmıştır. Bu diyalog Tablo $4^{\prime}$ te yer alan örüntü probleminin çözümünde, öğretmenin öğrencilerden şekli analiz etmeleri istediği süreçte yaşanmıştır.

Tablo 4

Ders İçinde Yaşanan Diyalog

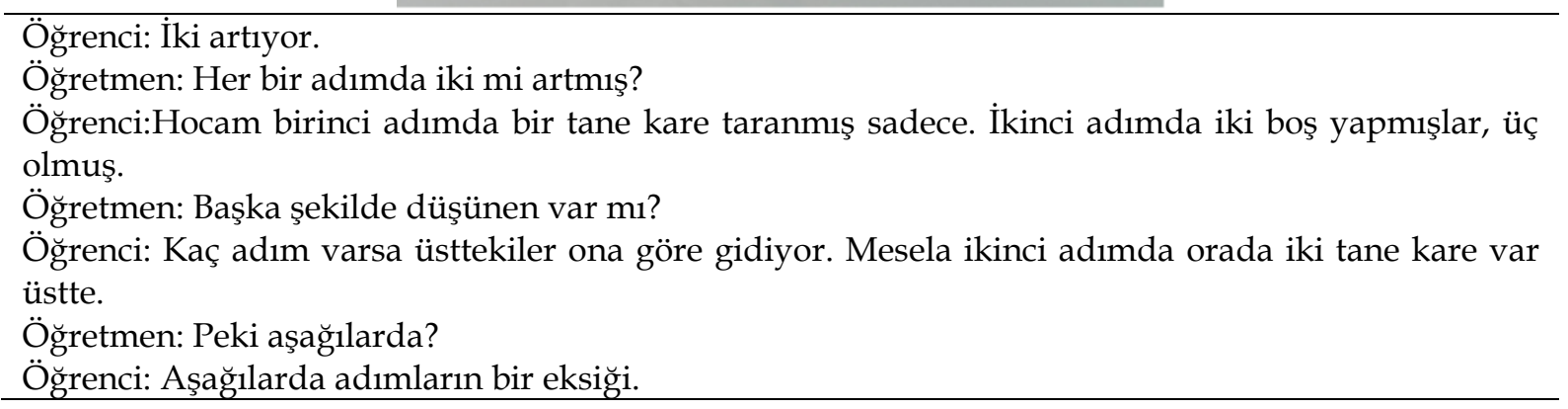

Öğrenciler burada da şeklin yapısını inceleyerek, oluşumuna dair ilişkiyi sözel olarak ifade etmişlerdir. Ancak öğretmen bu düşüncelerden hareketle dersini yönlendirmediği ve kendi açıklamalarıyla derse devam ettiği için öğrenciler sözel ifade ettikleri ilişkiyi $(n+n-1)$ şeklinde cebirsel forma dönüştürememişlerdir. Öğretmen bu etkinliklerde öğrencilerin ortaya koymuş olduğu sözel ilişkiyi diğer temsil çeşitleriyle ilişkilendirecek ortamı oluşturmadığ 1 ve etkinliğe kendi açıklamaları ile devam ettiğinden öğrenciler geri kalan etkinliklerde de benzer zorlukları yaşamaya devam etmişlerdir.

Öğretmen öğretim deneyi sürecinde oluşturulan TÖY'de varsayılan öğrenme ilerleyişindeki toplamsal ilişkiyi yazma adımını atlayarak öğrencilerden çarpımsal 
ilişkiyi yazmalarını beklemiştir. TÖY'e dayalı öğretim etkinliklerinin uygulanmasında öğrencilerin süreçleri ve düşünceleri takip edilerek düzenlemeler yapılması olası ve beklenir bir süreçtir. Ancak Damla Öğretmen'in etkinliklerinde öğretimler planlanan yolda gitmesine, öğretim deneyi sürecinde varsayılan öğrenci düşünceleri ortaya çıkmasına rağmen, öğretmen başarılı bir şekilde bunları öğretimlerine entegre edememiştir. Öğrenciler öğretimlerde etkili temsiller ilişkiler kurulamadığında cebirsel kuralları oluşturmada başarısız olmuşlar ve kuralları deneyerek bulma yoluna yönelmişlerdir. Bu tür bir örnek, Tablo 5'te verilen diyalogda ortaya çıkmıştır.

Tablo 5

Ders İçinde Yaşanan Diyaloglar

\begin{tabular}{|c|c|c|c|}
\hline Diyalog & \multicolumn{3}{|c|}{ Öğrencinin yazdığı çarpımsal ilişki } \\
\hline \multirow{6}{*}{$\begin{array}{l}\text { Öğrenci: Öğretmenim birinci adım bir artı üç } \\
\text { çarpı bir, ikinci adım bir artı üç çarpı iki. } \\
\text { Öğretmen: Yapar mısın tahtaya? Türkan nasıl } \\
\text { farkettin bunu? } \\
\text { Öğgrenci: Hocam dört var dedim ve sonra bir artı } \\
\text { üç çarpı bir. (Öğrenci yandaki tabloyu doldurdu.) }\end{array}$} & fsik Saym) & Porca $\leq-m, 33$ & \multirow{6}{*}{$\begin{array}{l}100 \cdot-2.2 ? \\
1,3 \cdot 100 \\
=30\end{array}$} \\
\hline & a & $41+31$ & \\
\hline & 2 & $71+32$ & \\
\hline & 3. & $13+34$ & \\
\hline & 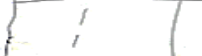 & & \\
\hline & & & \\
\hline
\end{tabular}

Yukarıda açıklandığı üzere Damla Öğretmen örüntü problemlerinin çözümünde daha önce varsayıldığı şekilde toplamsal ilişkileri yazdırıp çarpımsal ilişkiyi yazmadığından, sınıftan bir öğrenci Tablo 5'de verilen diyalogda görüldüğgü üzere deneyerek bir kural bulmuş ve tabloda yer alan çarpımsal ilişkileri bu kural doğrultusunda doldurmuştur. Burada öğrenci bir kural bulmuş olmasına rağmen sınıftaki diğer öğrenciler bu noktada henüz bir kural oluşturamamışlardır. Öte yandan öğretmen bu öğretim etkinliğinde tablo temsilini öğrencilerin kurala ulaşmasında bir araç olarak kullanamamış, bir amaç gibi görerek öğrenciye tabloyu doldurtmuş, bu yönde öğrencilere rehberlik edememiştir. Ayrıca burada amaç öğrencilerin temsiller oluşturmalarına rehberlik ederek anlamlı öğrenmelerini sağlamaktır. Bu öğretim etkinliğinde yer alan temsil kullanımı amacının dışına çıkmış, bir araç olarak oluşturulmasının ötesinde sanki tablo doldurmak etkinliğin amacı olarak görülmüş ve öğrenci bulduğu ilişki sonrasında tabloyu doldurmuştur. Öğretmen bu süreçte sorgulama ile öğrencilerin matematiksel ilişkileri açık şekilde yazmalarını sağlamak yerine kendisi açıklamalar yaparak ya da öğrencilerin ezbere buldukları yolları kullanarak bir kural yazmaya çalışmıştır. Ancak öğrencilerin bu açıklamalar üzerine düşünerek temsiller arası ilişkileri kavramsallaştıramadıkları ve temsiller arası ilişki kuramadıkları, dersin ilerleyişinde kural oluştururken ezbere yollar izlemelerinden anlaşılabilmektedir. Ancak öğretmen bu durumda da öğrenci yanıtının analizini yapıp dersin akışını değiştirme yoluna gitmemiştir.

Damla Öğretmen başlangıçta örüntü problemlerinde temsilleri araştırmada beklenildiği şekilde öğrencilerin temsil yapılandırmalarını destekleyecek şekilde etkili olarak kullanabilmiş değildi. Planlama oturumlarında öğretim etkinlikleri araştırmacı ve öğretmenler ile ortaklaşa planlandığından, bu noktaya kadar derslerde birçok temsil çeşidini kullanması zaten beklenilir bir durumdu. Ancak Damla öğretmen, öğrencilerin kendi düşünceleri ile temsilleri yapılandırmasına rehberlik etmesi, 
yapılandırılan bu temsilleri ders ile ilişkilendirmesi ve beklenilen temsiller arası ilişkileri kurması noktalarında etkili olamamıştır. Bundan sonraki süreçte öğretmenin bu eksiklikleri planlama oturumlarında kendi öğretim videoları üzerinden nasıl bir sorgulama yapılabileceği, öğrencilerin düşüncelerinin öğretime nasıl entegre edilebileceği ve temsiller arası ilişkilerin nasıl kurulabileceği başlıklarıyla ele alınmıştır.

\section{Emre Öğretmen'in Başlangıçtaki Temsil Kullanımı}

Emre Öğretmen' in başlangıç olarak ele alınan temsil kullanımında, öğrencilerin temsil kullanım yollarını sorgulayarak farklı düşüncelerini ortaya çıkardığı ancak bu düşüncelerden hareketle temsilleri kendisinin oluşturduğu yani kendi düşüncelerini ön plana çıkardığ1 görülmüştür. Diğer bir ifadeyle Emre Öğretmen öğrencilerin kendi temsil biçimlerini oluşturmalarını sağlamak için rehberlik edememiştir. Ayrıca Emre Öğretmen' in farklı temsil biçimleri arasında geçiş yapmada ve TÖY'ün uygulanması sürecinde istenildiği üzere farklı öğrenci düşüncelerini ilişkilendirerek dersine entegre etmede eksiklik yaşamıştır. Emre Öğretmen'in bu eksikliğine örnek olarak Şekil 2'de verilen kürdan sayısı probleminde ortaya çıkan iki farklı öğrenci düşüncesinden sadece bir tanesiyle derse devam etmesi gösterilebilir.

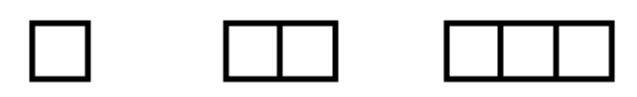

Şekil 2. Kürdan problemine ait şekil temsili

10. adımda var olan kürdan sayısının hesaplanmasına yönelik öğrencilerden biri "Dokuz kere üçer artıyor birde baştaki dördü ekleyince 31 ediyor", diğgeri ise "Beşinci adımda 16 tane kürdan varsa onuncu adımda 32 tane olur ama bir tane birleşme noktası çıkarılır 31 kalır" şeklinde iki farklı hesaplama yolu ortaya koymuşlardır. Öğretmen bu düşüncelerden birini göz önüne alarak, tablo temsilinin Şekil 3'daki gibi kendisi oluşturmuş ve şekil ile sembolik temsil arasında ilişkilendirme yapmaları için öğrencilere rehberlik edememiştir.

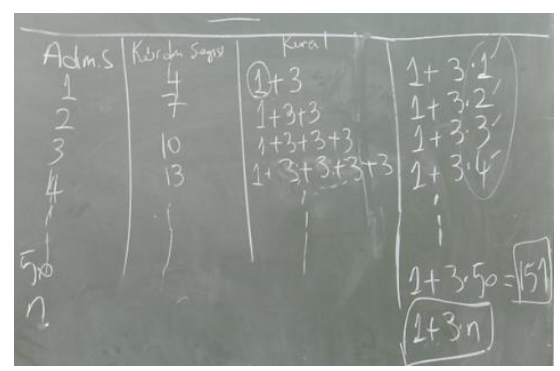

Şekil 3. Emre Öğretmen'in kibrit çöpü etkinliği için çizdiği tablo

Aynı zamanda, öğretmen ortaya çıkan iki farklı öğrenci hesaplama yolunu da birbiri ile ilişkilendirmemiş ve cebirsel olarak her iki yolun da aynı sonucu verdiğine dair bir ilişki kurmamıştır. Emre Öğretmen sadece bu etkinlikte değil, diğer etkinliklerde de ortaya farklı sözel durumlar çıksa dahi tek bir öğrencinin çözüm yolunu cebirsel olarak ifade etmiş ve diğeriyle bir ilişki kurmamıştır. Dolayısıyla öğrencilerin kendi çözüm yolları arasında ilişki kurmalarını sağlayacak bir öğretim gerçekleştirmemiştir. 


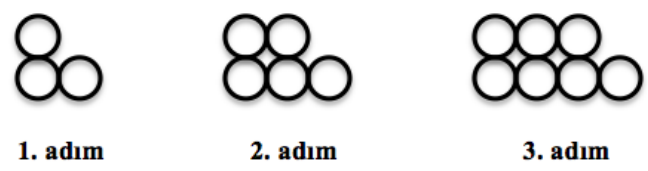

Şekil 4. Çemberlerle oluşturulmuş örüntü problemine ait şekil temsili

Öte yandan Emre Öğretmen' in dersleri boyunca öğrencilerin temsiller arasında da ilişki kurmalarını sağlayacak sorgulamayı gerçekleştirmediği, şekil üzerinde var olan ilişkileri açıklasa dahi tablo üzerinde sadece sayılar arasındaki ilişkilere odaklandığ1 görülmüştür. Bu durum Damla Öğretmen'de olduğu gibi tablonun öğrencilerin ilişkileri görmelerini sağlamak için bir araç olmaktan ziyade, amaç gibi kullanıldığını göstermektedir. Öğretmen başlangıçta şekil üzerine odaklanıp öğrencilerin bir kısa yol bulmasını sağlasa bile sonrasında tablodaki sayıların şekil ile ilişkilendirilmesini sağlayacak sorgulamayı kullanmadan kendisi açıklamış ya da hiç açıklamadan sadece sayılar üzerindeki ilişkilere odaklanmıştır. Örneğin Şekil 4'de yer alan herhangi bir adımdaki top sayılarını veren kuralın bulunması probleminde, öğretmen öğrencilerden tabloda ilk beş adımdaki top sayıları ile adım sayıları arasındaki ilişkiyi açıklamalarını istemiştir. Dersi açıklayan diyalog Tablo 6'da yer aldığı şekilde gerçekleşmiştir.

Tablo 6

Emre Öğretmen'in Dersini Açıklayan Diyaloglar

\section{Problemin çözümünün başlangıcında izlenilen yol}

Öğretmen: Birinci dersimizde kürdanlı bir örüntü yaptık. Şimdi bilyelerle bir örüntü yapacağız. 1., 2. ve 3. Adımı verilen bu örüntünün 4. ve 5. Adımlarını çizebilir misiniz? ... (Öğretmen öğrencilere her bir adımın çizimi için süre tanıdı.)

Öğretmen: İlk dersimizde bir tablo yapmıştık. Tabloyu kural bulmak için kullanmıştık. (Tahtada şekillerin altına 3,5,7,9 yazdı). İlişkimiz nedir? Acaba top sayısı ile adım sayısı arasında nasıl bir ilişki var?

\section{Problem çözümünün devamında izlenilen yol}

Öğretmen: Bir sabit, iki eklenmiş (Birinci adımın yanına bir artı iki yazdı.) İkinci adımda bir artı iki artı iki. Aynı şekilde üçüncü adımda bir artı iki artı iki artı iki şeklinde. (4. ve 5. adımı da yazdırdı.)

Öğretmen: Aynı şeyler bunun içinde geçerli sabit olanlar hangileri?

Öğrenci: Bir.

Öğretmen: Başka bir şey daha sabit.

Öğrenci: İki.

Öğretmen: Bir sabit bir de iki sabit değil mi? Peki kaç tane 2 var? Bunları kısa yoldan nasıl yazabilirim?

Öğrenci: Bir artı iki çarpı bir (1+2.1), bir artı iki çarpı iki (1+2.2). (Öğrenciler 3. ve 4. adımları hep birlikte sesli söylediler.)

Öğretmen: Peki n. adımda acaba kaç top sayısı olur?

Öğrenci: Bir artı iki çarpı n.

Öğretmen: Şimdi arkadaşlar demek ki bu örüntünün kuralı neymiş?

Emre Öğretmen tabloya vurgusuyla ve top sayılarıyla adım sayısı arasındaki ilişki sorusuyla, öğrencilerin şekilden uzaklaşarak bulacakları toplamsal ve çarpımsal ilişkilerde sadece sayılara odaklanmalarına neden olmuştur. Nitekim etkinliğin devamında şekil üzerine hiç dönmemiş tablo üzerindeki sayılardan devam ederek 
cebirsel ifade yazımına ulaşmış, dolayısıyla temsiller arası ilişkilendirme yapamamıştır. Öğretmen dersin başlangıcında öğrencilerin tablo temsilini öğrencilerin kendilerini oluşturmalarını sağlamadığı gibi, dersin devamında da öğrencilerin temsiller arasında ilişki kurmaları (şekil, tablo ve cebirsel temsil arasında) için öğrencilere rehberlik etmemiştir. Aksine "tabloyu kural bulmak için kullanmıştık" ifadesiyle, şekil ile cebirsel ifade arasındaki ilişkilendirmeyi vurgulamadığı görülmektedir.

Öğretmenlerin ilk hafta temsillerde yaşadıkları eksiklikler yukarıda yer verilen bulgularda açıklanmıştır. Bu eksikliklerin tespitinin ardından öğretim deneyi sürecinde öğretmenler ile Tablo 1'de yer alan mesleki gelişim etkinliklerine yer verilmiştir. Bu etkinliklerde öğretmenler kendi derslerinin videolarını izleyerek değerlendirmelerde bulunmuş, öğrenci düşüncesini kullanmak ve değerlendirmek amacıyla öğrenci görüşmeleri gerçekleştirmiş ve örnek ders senaryosu ile hazırlanmış örnek bir ders videosu izlemişlerdir. Bu süreçte öğretmenlerin temsillerin kullanımına yönelik gelişimini gösteren bulgular bir sonraki bölümde açıklanmıştır.

\section{Damla Öğretmen'in Gelişiminin ardından Temsil Kullanımı}

Damla Öğretmen'in ilk hafta temsillerin ilişkilendirilmesinde ve öğrencilerin temsillerle ilgili düşüncelerinin derse entegre edilmesinde görülen eksiklikleri giderilmiştir. Tablo 7 'de verilen örüntü probleminde Damla Öğretmen'in bu gelişimini gösteren örnek açıklanmıştır. Bu problem, ayrıca örnek ders senaryosunda ve örnek ders videosunda çözülen problemdir. Birincisi, Damla öğretmen bu problemde öğrenci düşüncelerinin şekil temsili ile ilişkilendirilmesi için öğrencilere yönlendirmede bulunmuştur. Örneğin, öğretmen 4. ve 5. adımın oluşturulmasında ortaya çıkan öğrenci düşüncelerini öncelikle şekil üzerinde göstermelerini istemiştir.

Tablo 7

Çözülen Örüntünün Şekli ve Çözüm Sırasında Yaşanan Diyaloglar

\begin{tabular}{l}
\hline 1. diyalog \\
\hline Öğretmen: Şekil üzerinde gösterebilir misin bana? \\
Öğrenci: Hocam ilk baştaki iki altıgenle sondaki iki altıgen sabit kalmış. (Öğrenci ilk adımda sağ ve \\
soldaki iki altıgeni işaretledi.) \\
Öğretmen: İkinci ve üçüncü adımda nasıl oluyor? \\
Öğrenci: ... (şekil üzerinde beşinci adımda baştaki ve sondaki iki altıgeni işaretledi.) \\
Öğretmen: Bunlar hep sabit, diğerleri nasılı değişmiş işaretlediklerinin dışında kalanlar? \\
Öğrenci: Onlar adım sayısına göre (Mavileri işaretledi.) \\
Öğretmen: Mavi dışında hesaba katmadıklarında var. Onlar nasıl değişmiş? \\
Öğrenci: Bunların arasına ikili girmiş, sonra yine aynı şey olmuş. (Üçlü sütunların arasını kastediyor.) \\
\hline
\end{tabular}

İlk diyalogda görüldüğü üzere öğrenci altıgen modellerin en başındaki ve en sonundaki iki altıgen içeren sütunu sabit tutarak aradaki altıgenlerin sayısının nasıl değiştiğini inceleyen bir düşünce ortaya koymuştur. Damla Öğretmen de bu düşünceyi analiz etmiş ve öğrencinin düşüncesine yönelik sorular sorarak açıklanmasını istemiştir. Ayrıca öğrencinin düşüncesini tahtada çizili olan şekil 
üzerinde açıklamasını isteyerek öğrencinin şekil temsili ile olan ilişkisini kurmasını ve bu ilişkinin sınıf için görünür olmasını sağlamıştır. Damla Öğretmen aynı problemin devaminda, 2. diyalogda yer alan bir başka öğrenci düşüncesinde ise yine önce düşüncenin şekil ile ilişkilendirilmesini istemiş, ardından da sembolik temsile geçişini gerçekleştirmiştir.

$\mathrm{Bu}$ yolda öğrenci şekil örüntüsünün en başındaki iki altıgeni sabit tutmuş ve ardından her bir şeklin oluşumunda dört altıgen eklendiğini şekil üzerinde açıklamıştır. Öğretmen bunun üzerine sembolik temsile geçiş yapmış ve bu düşüncesinin sembolik olarak nasıl ifade edileceğini sormuştur. Her zaman tablo oluşturmaya meyilli ve bundan önceki derslerde de tablo oluşturduğunda dersin adım adım ilerlemesine engel olduğu söylenebilecek olan öğrenciyi öğretmen bu derste engelleyerek tablo oluşturmamasını ve ilişkiyi açık şekilde yazmasını istemiştir. Öğrenci ardından ilişkiyi önce toplamsal olarak, sonra da çarpımsal olarak ifade etmiştir. Öğretmen' in bu hamlesinin diğer öğrencilerin dersten kopmasını engellediği ve yazılan yolları anlamalarına yardımcı olduğu söylenebilir. Diğer taraftan Damla Öğretmen bundan önceki her örüntü probleminin çözümünde mutlaka tablo temsili kullanmış ancak tablo temsilinin diğer temsiller ile ilişkisini kurmayı gerçekleştirememişti.

Tablo 8

Örüntü Probleminin Çözümü Sırasında Yaşanan Diyaloglar

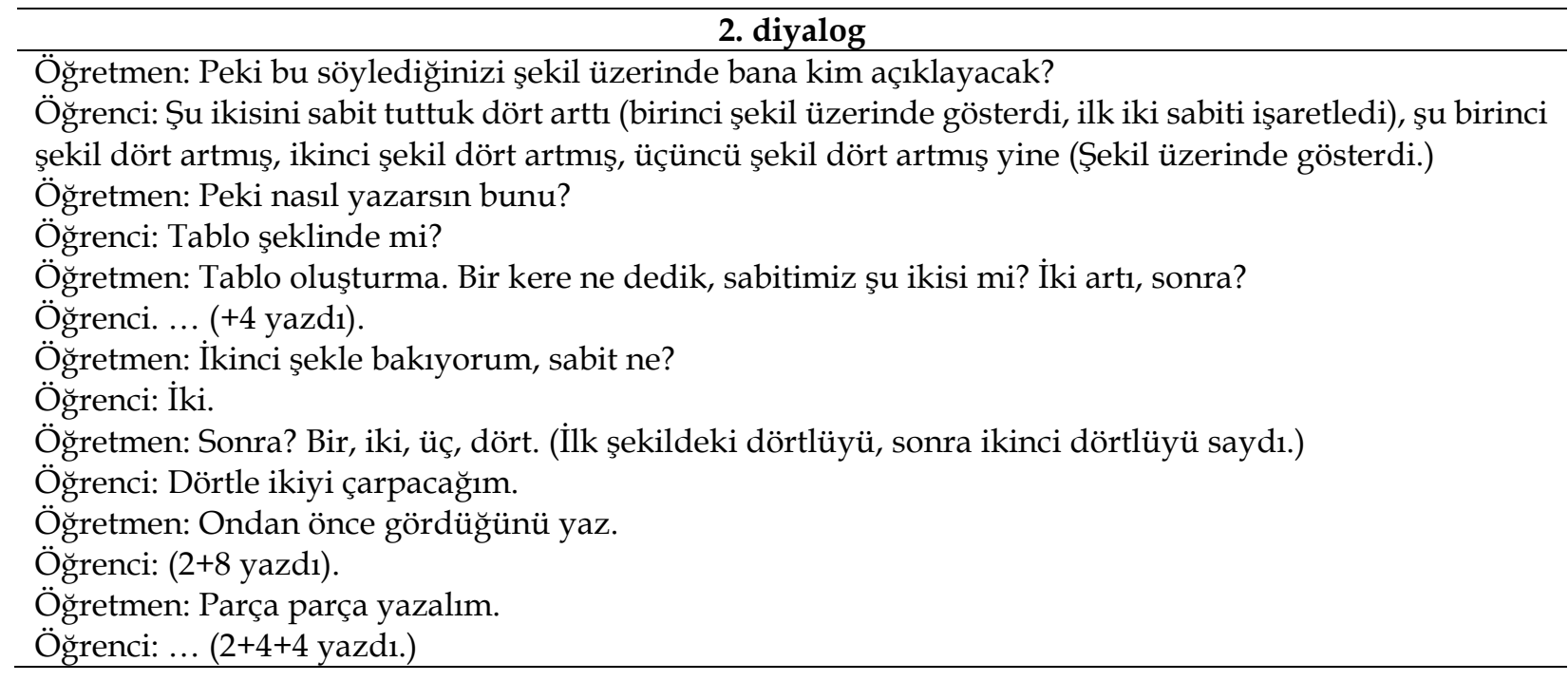

Ancak bu derste önceki derslerine benzer şekilde bir tablo oluşturmamasına karşın Tablo 9'daki şekilde verilenler düzenli olarak yazılmış ve yazılan ifadelerin öğrenci düşünceleri ve şekil temsili ile ilişkileri kurulmuştur.

$\mathrm{Bu}$ dersin öncesinde planlama oturumunda araştırmacının daha önce hazırlamış olduğu ve temsillerin kullanımının etkili kullanımına örnek olabilecek bir video üzerinde temsillerin ilişkisel olarak kullanımının nasıl gerçekleştirildiği incelenmişti. Yapılan video incelemesinin, öğretmenin bu hafta gerçekleştirdiği uygulamada tablo ve temsiller arasındaki ilişkileri kullanımı üzerinde etkili olduğu söylenebilir. 
Tablo 9

Damla Öğretmen'in Sinıfinda Kullanılan Tablo Temsili ve Sembolik Temsiller

\begin{tabular}{lll}
\hline $2+4$ & $2+4.1$ & $2(1+1)+1.2$ \\
$2+4+4$ & $2+4.2$ & $2(1+2)+2.2$ \\
$2+4+4+4$ & $2+4.3$ & $2(1+3)+3.2$ \\
$2+4+4+4+4$ & $2+4.4$ & $2(1+4)+4.2$ \\
$2+4+4+4+4+4$ & $2+4.5$ & $2(1+5)+5.2$ \\
$\ldots$ & $\ldots$ & $\ldots$ \\
& $2+4.50$ & $2(1+50)+50.2$ \\
& $2+4 . \mathrm{n}$ & $2(1+\mathrm{n})+\mathrm{n} .2$ \\
\hline
\end{tabular}

Damla Öğretmen'in gelişiminin görüldüğü ve problemin çözümünde örüntü yaklaşımının kullanıldığı bir başka öğretimi aşağıdaki şekilde gerçekleştirilmiştir. Bu öğretimde yine öğretmen temsillere yönelik olarak ilişkisel kullanım yolunu benimsemiş ve hem tablo ile sembolik temsil arasında hem de şekil ile sembolik temsil arasında ilişkilendirmeleri ön plana çıkarmış ve öğrencileri ilişkisel kullanımları konusunda yönlendirmiştir. Bu yönlendirme ve öğretimde ortaya konulan temsil ve diyaloglar Tablo 10'da yer almaktadir.

Tablo 10

Damla Öğretmen'in Sınıf Içinde Çözdüğ̈̈ Problem, Oluşturulan Tablo ve Yaşanan Diyaloglar

Turkuaz isimli bir kafede internet kullanımında bir bilgisayara açmak için 2 lira ve her saat için de 3 lira ödenmektedir. Sanal dünya isimli kafede ise internet kullanında bilgisayarı açmak için para ödenmezken, internet kullanımının saatine 5 lira ödenmektedir. Buna göre Onur hangi internet kafeye giderse daha az para ödemiş olur?

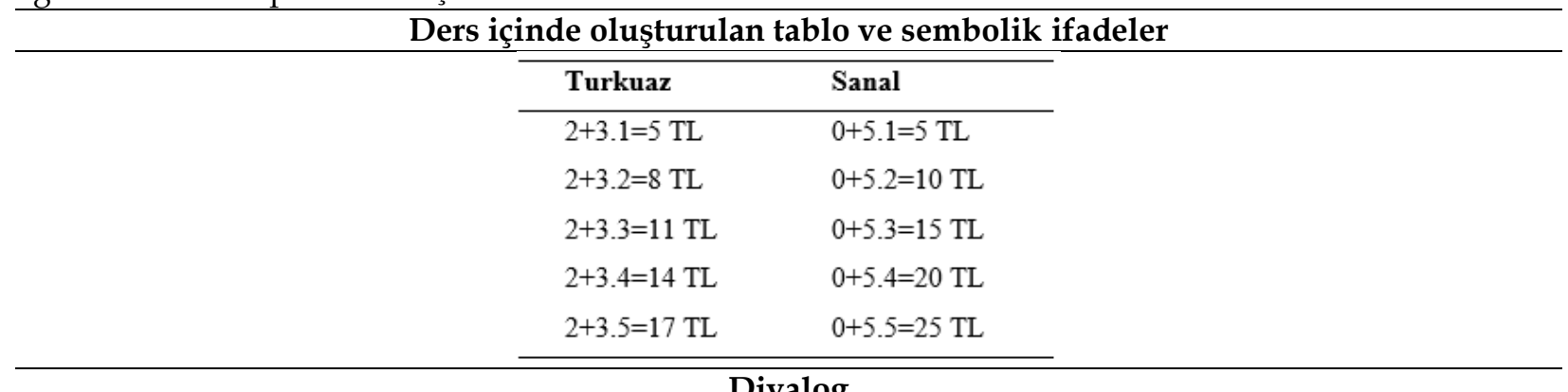

Öğretmen: Sonuç olarak ne diyorsun?

Diyalog

Öğrenci: Cebirsel ifade yazabilirim.

Öğretmen: Nasıl yazabiliriz?

Öğrenci:İki sabit kalıyorsa iki artı deriz. İki artı üç çarpı bir. Kaç saatse öyle yazarız.

Öğretmen: Kim yazacak tahtaya?

Öğrenci: Turkuaz açmak için 2 lira veriyormuş. Her saat içinde üç lira veriyormuş. Sanal dünya da açmak için para vermiyormuş, her saat için beş lira veriyormuş. (Tablo oluşturdu, 2+3.1 TL ve 0+5.1 TL yazdı.) Öğrenci: Kuralı söyleyeyim mi?

Öğretmen: Söyleme. Bakalım önce bir saat, iki saat, üç saat durunca kim ne kadar para ödüyormuş?

Öğrenci: ... (beşinci saate kadar tabloyu doldurdu.)

Öğrenciler ile kafelerden hangisinin ücretinin daha hesaplı olduğunu konuşmalarının ardından öğrencilerden biri cebirsel ifade yazabileceğini söylemiş ve farklı bir öğrenci de tahtada tablo oluşturmuştur. Bu noktada öğretmen cebirsel 
ifadenin yazımına geçilmeden önce tüm tablonun doldurulmasını sağlamış ve ardından tablo üzerindeki verileri inceleyerek cebirsel ifade yazımına geçmiştir. Bir öğrenci ilk anda kuralı bulmuş olmasına karşın öğretmen onu durdurmuştur. Öğretmen bu hamlesiyle tablo kullanımına önem verdiği, tablo üzerindeki sembolik ifadeleri inceleyerek kurala ulaştığı ve bu sayede tüm öğrencilerinde ilerleyişini göz önünde bulundurduğu söylenebilir.

Temsillerin ilişkisel kullanımına yönelik olarak farklı bir örüntü probleminde öğrencilerin bulmuş oldukları sözel durumları "Peki bir ile on ikiyi topladım dedin. Bu şekil üzerinde nasıl gösterirsin onu bana?" gibi yönlendirmelerle öğrencilerin şekle odaklanmalarını sağlamaya çalışmıştır. Aynı şekilde üçüncü problemde de şekil ile sembolik temsil arasında ilişki kurmuş ve öğrencilerin Şekil 5'te gösterilen şekli çizmelerini sağlamıştır.

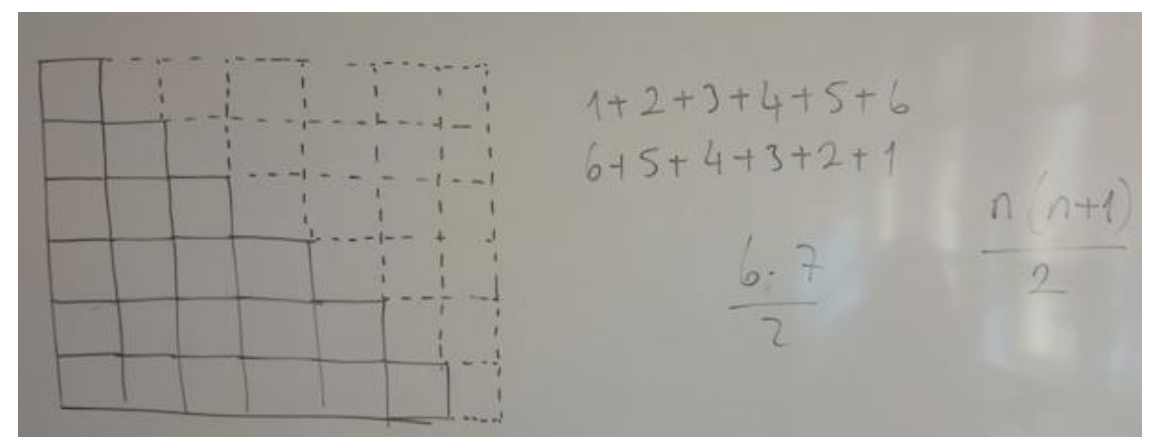

Şekil 5. Üçüncü Problemin Çözümü için Oluşturulmuş Şekil ve Sembolik Temsil

Öğretmen bunun sembolik temsillerini de yine şekilde görüldüğü üzere ifade ettirmiştir. Sonuç olarak Damla Öğretmen her üç problem durumunda da kullanilabilecek sözel durumlar ile tablo, şekil ve sembolik temsillerin ilişkilendirmesini sağlamıştır.

\section{Emre Öğretmen'in Gelişiminin ardından Temsil Kullanımı}

Emre Öğretmen'de ilk hafta ortaya çıkan kendi düşüncelerini öne çıkarma durumu değiştirilmiş ve öğretmenin farklı öğrenci düşüncelerini birbirleriyle ve temsillerle ilişkilendirmekte yaşadığı eksiklikleri giderilmiştir. Emre Öğretmen ilk olarak şekil temsili ile öğrenci düşüncelerini ve diğer temsilleri birbirleri ile ilişkilendirmiş; kendi düşünceleriyle değil öğrenci düşüncelerini kullanarak dersine devam etmiştir. Örneğin öğretmen Tablo 11'de görülen şeklin yapısını öğrencilere inceletmiştir. Bu inceleme sürecinde yaşanan diyaloglar Tablo 11'de görülmektedir.

Öğrenciler düşüncelerini açıklamalarının ardından öğretmen düşünceleri görünür kılmak amacıyla öğrencilere sorular sormuş ve şeklin yapısını inceletmiştir. Öğrencilerin şeklin oluşumunu açıklamalarının ardından ise 50. adımda var olan beyaz karo sayısını sormuştur. Yukarıdaki diyalogda öğretmenin şekil temsilinde öğrencilerin görebildiği yakın adımlarda buldukları ilişkileri kullanarak 50. adımdaki karo sayısına dair hesapları görülmektedir. Bir başka örnekte ise öğrenci ilişkiyi 1.8=8, $2.5=10,3.4+2=14$ olarak açıklamıştır. Öğretmende öğrencinin yazmış olduğu sembolik ilişkinin bileşenlerinin ne olduğunu sorduktan sonra şeklin yapısını yeniden incelemesi için öğrenciyi yönlendirmiştir. Bir başka ilişkilendirme de ise şeklin yapısı 
ile sembolik temsil arasında ilişki kurması söz konusudur. Öğrenciler şeklin yapılarını açıklamalarının ardından sembolik yazıma geçilmiş ve öğrenciler şekil ile ilişkisini sembolik temsiller ile açıklamışlardır.

Tablo 11

Emre Öğretmen'in Sınf İçinde Çözdüğ̈̈ Probleme Ait Şekil ve Süreçte Yaşanan Diyaloglar

\begin{tabular}{l}
\hline \\
\hline Öğretmen: Bakın mesela bu adımda veya bu adımda fark etmez, sabit olan ne? \\
Öğrenci: Oradaki üç tane olanlar hiç değişmiyor? Karşılıklı ve yan yana olanlar hiç değişmiyor, ama \\
yanlarındakilerin hepsi bazen bir oluyor, bazen iki oluyor. \\
Öğretmen: Tamam neye göre değişiyor o zaman onlar? \\
Öğrenci: Adım sayısına göre değişiyor. \\
Öğretmen: Sabit olanlar neymiş? \\
Öğrenci: Sabit olanlar üçler (Şekil üzerinde sol kenardaki üçlü sütunu gösterdi.) \\
Öğretmen: Sağ ve soldaki üçler hiç değişmiyor demi? Peki o üsttekiler nasıl değişiyor? \\
Öğrenci: Hocam üstteki kareler artarak gidiyor işte. \\
Öğgretmen Neye göre gidiyor? \\
Öğgrenci: Adım sayısına göre. \\
Öğgretmen: Peki adım sayımız belli, yandakiler zaten sabit. 50.adımda kaç tane olur o zaman?
\end{tabular}

Emre Öğretmen'in şekil temsilini ilişkisel olarak kullandığı bir başka öğretimi de örnek senaryo ve videoda gösterilen problem üzerinde gerçekleşmiştir. Emre Öğretmen Tablo 12'de görüldüğü üzere ilk olarak öğrencilerin şekil üzerinde çalışmalarına önem vermiş ardından şekil ile öğrenci düşüncelerini ilişkilendirmiştir. 1.diyalogda öğrenci ilk deseni sabit tutarak diğer her bir desenin dörder arttığını ifade etmiş; öğretmen de öğrencinin söylemiş olduğu yolu şekil üzerinde göstermesini istemiştir. Benzer başka bir yerde de yine şekil üzerinde öğrencinin yolunu açıllaması için sorular sormuştur. 2. diyalogda ise öğrenci sütunların sayısına dayalı bir yol önermiş; öğretmen de öğrencinin açıkladığı yolu şekil ile ilişkilendirmek için sorular sorarak göstermesini istemiştir. Hem de bu yolla diğer öğrencilerin de ortaya çıkan yolu şekil üzerinde görmelerini sağlamaya çalışmıştır. Emre Öğretmen ayrıca şekil ile sembolik temsil arasında da ilişki kurmuştur. Gerçekleştirilen bu derste öğrencilerin şekil üzerinde yollarını açıklamalarının ardından, bu yolları ifade edildiği şekliyle sembolik temsile dönüştürmelerini istemiştir. Her bir yol farklı şekillerde sembolik olarak Tablo 12'de görüldüğü şekilde ifade edilmiştir. Sonuç olarak, Emre Öğretmen hem öğrenci düşüncesiyle hem de sembolik temsil ile ilişkilendirerek şekil temsilini ilişkisel olarak kullanmıştır. 
Tablo 12

Emre Öğretmen'in Sını İçi Diyalog Örnekleri

\begin{tabular}{|c|c|}
\hline 1. diyalog & 2. diyalog \\
\hline $\begin{array}{l}\text { Öğrenci: İlk desen hariç diğerlerinin } \\
\text { sarıları dörder dörder artmış. } \\
\text { Öğretmen: İşaretle onları. Onlar neymiş? } \\
\text { Öğrenci: Bu ilk altı tane. Diğerleri de } \\
\text { dörder dörder artıyor. (Şekil üzerinde } \\
\text { çizdi.) ... } \\
\text { Öğretmen: Tamam bu sarıları nasıl } \\
\text { sayabiliriz? } \\
\text { Öğrenci: 2, 4, 6, } 8 \text { (Şekil üzerinde sütunları } \\
\text { gösterdi.) } \\
\text { Öğgretmen: Her sütundaki sarıları sayarım } \\
\text { diyor. Kaç sütun var? } \\
\text { Öğrenci: 11. (Beşinci adımda.) }\end{array}$ & $\begin{array}{l}\text { Öğrenci: Üçlüden bir tane var, ikiliden iki tane var. } \\
\text { Öğretmen: Üçlüden bir tane var... (Öğrencinin söylediğini } \\
\text { düşündü.) } \\
\text { Öğrenci: Evet, çünkü üçlü adım sayısına göre artıyor. } \\
\text { İkiliden iki tane var, adım sayısının bir fazlasına göre } \\
\text { artıyor. } \\
\text { Öğretmen: İkinci adımda? } \\
\text { Öğrenci: İkinci adımda da üçlüler iki tane, ikililer üç tane. } \\
\text { İkililer adım sayısının bir fazlası. Üçlüler adım sayısına } \\
\text { göre gidiyor, ikililer adım sayısının bir fazlasına göre } \\
\text { giddiyor. } \\
\text { Öğretmen: Altına yolunu nasıl yazarsın? } \\
\text { Öğgenci: (1.3+2.2)-1 yazdı. Mavi olduğu için 1'i çıkarıyoruz. }\end{array}$ \\
\hline
\end{tabular}

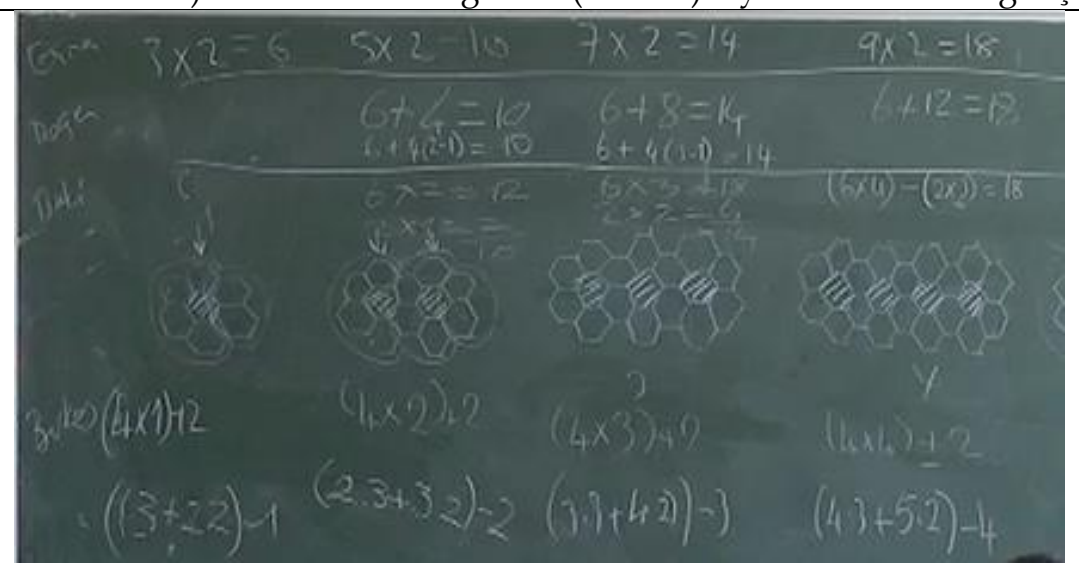

Emre Öğretmen'in temsillerin kullanımına yönelik olarak tablo, şekil ve sembolik temsiller ile sözel ifadeleri, diğer bir ifade ile temsilleri ilişkisel kullandı̆̆ görülmüştür. Örneğin, ilk problemin çözümünde Şekil $6^{\prime}$ da verilen tablo temsilini kullanarak verilerini düzenlemiştir.

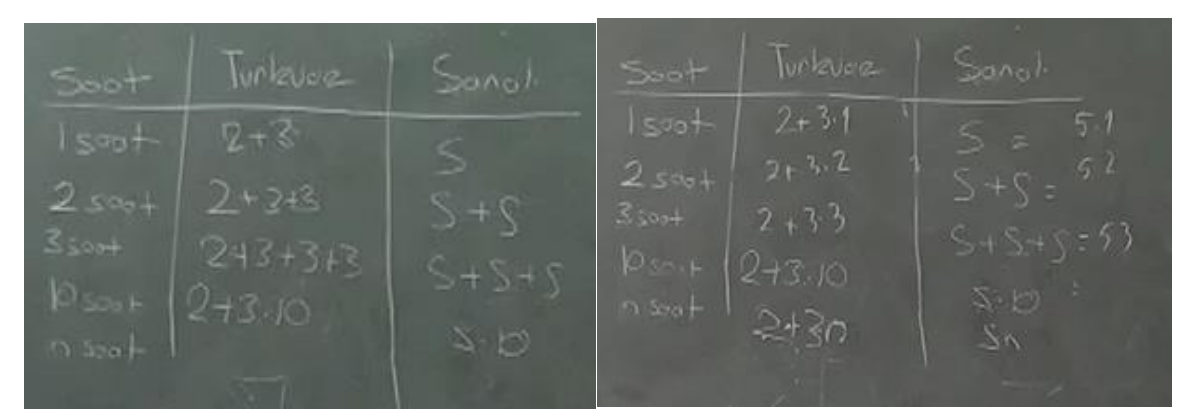

\section{Şekil 6. Emre Öğretmen'in Derslerinde Oluşturulan Tablo Temsilleri}

Emre Öğretmen öğrencilerin problem verilerini düzenlemek için tablo kullanmalarına özen göstermiş ve tablodaki veriler üzerinden hareket ederek öğrencilerin cebirsel ifade yazımına ulaşmalarını sağlamıştır. Öğretmen ilk olarak tablo üzerinde toplamsal ilişkileri düzenlemiş, ardından da çarpımsal ilişkileri 
yazarak sembolik temsile geçiş yapmıştır. Diğer bir ifade ile tablo ile sembolik temsilini ilişkisel şekilde kullanmıştır. Diğer problemde de benzer şekilde Şekil 7'de 1. Görselde yer alan şekil temsilleri ile 2. Görselde yer alan sembolik temsiller arasında ilişki kurmuştur.

1. Görsel

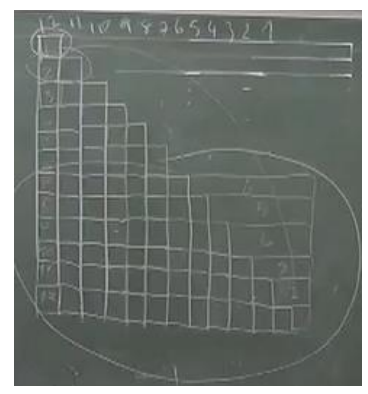

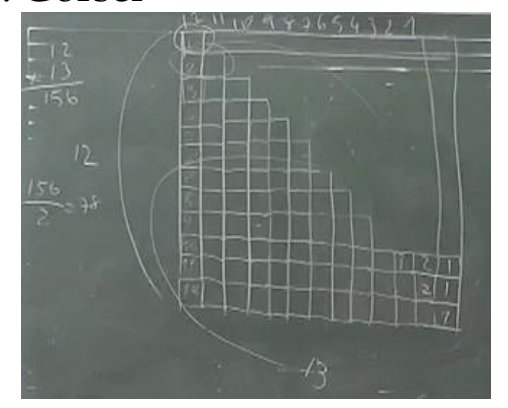

2. Görsel

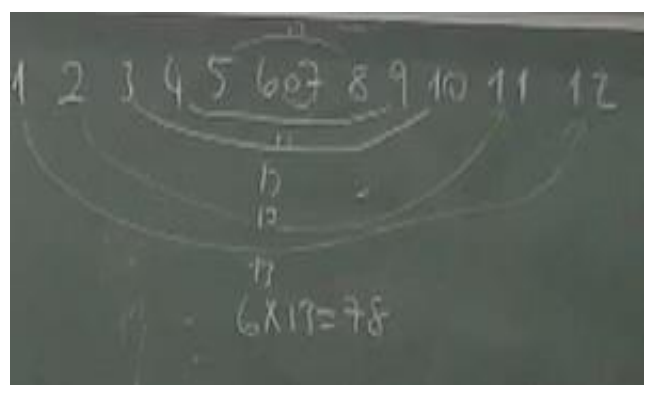

\section{Şekil 7. Emre Öğretmen'in Dersinde Oluşturulan Şekil Temsilleri}

Emre Öğretmen'in dersinde ortaya çıan iki farklı öğrenci çözüm yolu Şekil 12 'de 1. Görselde yer alan şekil temsilleri ile açıklanmıştır. Bu açıklamanın ardından 2. görselde yer alan aritmetik sembolleştirme yapılmıs ve ardından cebirsel sembolleştirmeye geçilmiştir. Emre Öğretmen'in yukarıda belirtilen temsiller arası ilişkilendirmeyi açıklayan bir diyalog Tablo $13^{\prime}$ te yer almaktadır.

Tablo 13

Emre Öğretmen'in Temsiller Arası İlişki Açıklamaları

Emre Öğretmen'in sınıfında yaşanan diyalog

Öğretmen: Burada 1'den 20'ye kadar olan sayılar olsaydı nasıl olacaktı?

Öğrenci: 1'i 20'ye götüreceğiz, 2'yi 19'a götüreceğiz, 21 olur.

Öğretmen: Peki kaç tane 21 olur?

Öğrenci: 20'yi 2'ye böleceğiz. 10 tane 21 olur.

Öğretmen: O zaman 1'den 21'e kadar olan sayıların toplamı ne olacak?

Öğrenci: 210. Sondakiyle baştakini toplayacağız. Sondakini 2'ye böleceğiz.

Öğretmen: Evet baştakiyle sondakini topluyoruz. Sondakini 2'ye bölüp çarpiyoruz.

$\mathrm{Bu}$ derste Emre Öğretmen öğrencilerin düşüncelerini öncelikle şekil ile de ilişkilendirerek sözel olarak açıklamalarını beklemiş ve ardından da açıklanan bu düşünceler sembolik olarak ifade edilmiştir. Sonuç olarak Emre Öğretmen temsiller açısından zengin bir ders işlemesinin yanında temsillerin ilişkisel kullanımına da özen göstermiştir.

\section{Sonuç ve Tartışma}

$\mathrm{Bu}$ araştırmada ortaokul matematik öğretmenlerinin TÖY'e dayalı öğretimlerinde temsil kullanımlarının ve temsiller arası ilişkilendirme becerilerindeki gelişimlerinin incelenmesi amaçlanmıştır. Bu amaçtan hareketle öğretmenlerle çeşitli mesleki gelişim etkinlikleri gerçekleştirilmiştir. Bu etkinlikler problem çözme ve bunların öğretimlerde kullanımı, sınıf içi durum analizleri, öğretim videolarının ve öğrenci görüşme kayıtlarının değerlendirilmesi ile araştırmacılar tarafından çekilmiş örnek ders videolarının incelenmesidir. Bu etkinlikler ile Damla ve Emre Öğretmen'in sınıf içi uygulamalarında öğrenci düşüncelerinden hareketle temsillerin kullanımı için 
öğrencileri yönlendirmeleri ve öğrencilerde temsillere ilişkin ortaya çıkan düşünceleri organize ederek aralarında ilişki kurmada onlara rehberlik etmeleri sağlanmaya çalışılmıştır.

$\mathrm{Bu}$ çalışma kapsamında üzerinde durulan temsil kullanımlarının gelişimine yönelik gerçekleştirilen mesleki gelişim etkinlikleri sonucunda öğretmenlerin iki noktada geliştikleri görülmüştür. Birincisi öğretmenler başlangıçta temsilleri sadece yüzeysel olarak kullanırken araştırmanın sonlarına doğru temsilleri kullanımları kavramsal olarak değişmiştir. Örneğin örüntü problemlerinde başlangıçta şekil ve tablo temsilini daha yüzeysel kullanırken, araştırmanın sonunda temsilleri daha yapısal olarak ele almış ve derinlemesine inceleyerek kullanmaya başlamışlardır. Öğretmenler gerçekleştirdikleri öğretimlerin tamamında, planlarda yer verildiği üzere çoklu temsilleri kullanmışlardır. Ancak bu kullanım ilerleyen zamanlarda daha etkili bir boyut kazanmıştır. Öğretmenler başlangıçta kendi öğretimlerinde çekilmiş video bölümlerini izleyerek; öğretimlerinin üzerine tartışmalar gerçekleştirmişlerdir. Öğretmenlerin kendi öğretim videolarını izlemeleri ve bunlar üzerine tartışmaları sonucunda öğrenmeleri birçok araştırmanın konusu olmuştur (Borko, Jacobs, Koellner ve Swackhamer, 2015; Schwartz ve Karsenty, 2020; Seidel, Stürmer, Blomberg, Kobarg ve Schwindt, 2011). Bu araştırmanın sonuçları ile alan-yazında yer alan araştırmaların sonuçları tutarlılık göstermektedir. Öğretmenlerin kendi öğretimlerine ait video bölümleri izlemeleri onların öğretim uygulamalarını geliştirmiştir. Karsenty (2018) öğretmenlerin hem kendi ve hem de meslektaşlarının öğretimlerini izlediğinde, çeşitli çıkarımlar yaparak ve bu videolar ile kendi öğretimlerini kıyaslayarak; öğretimlerine yönelik öğrenmeler gerçekleştirdiklerini ifade etmektedir.

Öğretmenlerin birbirlerinin öğretim videolarını izlemesine ek olarak, mesleki gelişim etkinliklerinden bir tanesi de araştırmacılar tarafından hazırlanmış örnek öğretim videosunun izlenmesi ve bunun üzerine tartışılması olmuştur. Bu örnek videonun izlenmesinin ardından, öğretmenlerin öğretimlerinde daha çarpıcı bir değişiklik meydana gelmiştir. Bunun nedeni, öğretmenlerin tanımadıkları meslektaşlarını izlerken daha rahat yorumda bulunabilmeleri ve etkili bir öğretimi uygulama içerisinde görmeleri de bu değişime katkı sağlamış olabilir. Arcavi ve Schoenfeld (2008), öğretmenlerin tanıdık olmadıkları meslektaşlarının videolarını izlediklerinde, özgür yorum yapmalarını sağlayacak tarafsız ortam yaratıldığından daha etkili öğrenmelerin gerçekleşebileceğini ifade etmektedir. Araştırmacıların bu çıkarımı, bu araştırmanın sonucu ile de doğrulanmıştır.

İkinci olarak da çoklu temsilleri öğrencileri düşüncelerinden hareketle bir araç olarak kullanarak, bu temsiller arasında ilişkilendirmeyi yapabilmişlerdir. Araştırmanın başlangıcında kullandıkları temsillerde herhangi bir ilişkilendirme yapılmazken, araştırmanın sonlarına doğru temsiller arasındaki ilişkilendirmelere yer vermişlerdir. Ayrıca öğrencilere farklı temsil biçimlerini oluşturmaları konusunda da yönlendirmelerde bulunmuşlar ve öğrencilerin temsilleri ilişkilendirmeleri için rehberlik etmişlerdir. Diğer bir ifadeyle, problemlerin çözümünde öğrenci düşüncelerini sürece dâhil etmişler ve bu düşünceleri de temsiller aracılığıyla ifade etmeleri için öğrencileri yönlendirmişleridir. Bu rehberliği başlangıçta yapmış oldukları sayısal ve cebirsel temsil üzerinde yapmış oldukları açılamalardan, temsil kullanımı ve temsilleri öğrencilerin oluşturmaları konusunda yönlendirmeleriyle gözlemlenmiştir. Öğretmenlerin öğrenci düşüncelerini öğretimlerinde temsil 
kullanımı ile etkili ilişkilendirmelerini, onların öğretim videoların izleme ve bunun yanında örnek öğrenci görüşmelerini değerlendirme etkinliklerinin desteklediği düşünülmektedir. Alan-yazında bahsedilen mesleki gelişim etkinlikleri aracilığıyla, öğretmenlerin etkili sınıf tartışmaları gerçekleştirebildikleri ve öğrenci düşüncelerini derslerle ilişkilendirebildiklerini gösteren ve bu çalışma ile paralel birçok araştırma sonucu yer almaktadır (Borko vd., 2015; Seidel vd., 2011; Sherin ve van Es 2009). Aynı zamanda bu süreçte öğretmenler başlangıçta üzerinde durmadıkları ve öneminin farkında olmadıkları çoklu temsillerin özellikle cebirde anlamlı öğrenmeyi sağladığının farkına da varmışlardır. Bu farkındalık çalışmanın kazançlarından biridir. Diğer yandan mesleki gelişim etkinlikleri sürecinde öğrencilerin tahmini öğrenme süreçleri ele alınırken temsiller işe koşulmuş ve bu temsiller üzerinden öğrencilerin kavramları nasıl içselleştirebilecekleri planlanmıştır. $\mathrm{Bu}$ nedenle öğretmenlerde temsil kullanımına yönelik yolların gelişmesinde TÖY'lerinin etkili olduğu da söylenebilir.

$\mathrm{Bu}$ araştırmada matematik öğretmenlerinin temsil şekillerini kullanmadaki bilgileri ve bu bilgiyi öğretimlerine yansıtma becerileri gelişme göstermiştir. Mesleki gelişim programlarının öğretmenlerin bilgi ve becerilerini geliştirdiği, böylece öğretimde bir gelişme sağlandığı (Higgins ve Parsons, 2009) dikkate alındığında bu düşünce daha da güçlenmektedir. Araştırma da kullanılan öğretmenlerin kendi öğretim videolarından bölümler izleyerek tartışma, tanımadıkları meslektaşlarının videolarını izleme ve gerçekleştirdikleri öğrenci görüşmelerini değerlendirme etkinliklerinin, öğretmenlerin temsil kullanımına yönelik öğretim uygulamaların etkili şekilde değiştirdiği söylenebilir. Akkoç ve arkadaşları da (2011) yürüttükleri projelerinde matematik öğretmen adaylarının ders planlarında fonksiyon kavramında iki gösterim şekli arasında bağlantılar kurduğunu belirtmişlerdir. Benzer şekilde öğretmen adaylarının da fonksiyon kavramına yönelik gösterim şekilleri arasında geçişler yapmada zorluk yaşadıkları Even (1998) tarafından da vurgulanmıştır. Uygulama sonrasında ise araştırmadaki katılımcı öğretmenler, fonksiyon kavramını öğretirken daha fazla gösterim şekli arasında geçişler yapmıştır. Üç ve daha fazla gösterim şekli arasında geçişler yapan öğretmen sayısında artış gözlenmiştir. Bu durum matematik öğretmenlerinin gösterim şekilleri arasında geçiş yapmadaki bilgilerinin de geliştiğini göstermektedir. Bu sonuç Akkoç vd.'lerinin (2011) araştırmasındaki matematik öğretmen adaylarının aldıkları eğitimin sonrasında fonksiyon kavramında daha fazla gösterim şekli arasında geçişler yapmada daha başarılı bir yaklaşım sergiledikleri sonucu ile paraleldir. Bu çalışma öğretmenlerin mesleğe atıldıktan sonraki süreçte desteğe gereksinimlerinin olduğunu ve yapılan mesleki gelişim etkinliklerinin sonucunda öğretmenlerin matematik öğretim bilgilerinin yanı sıra sınıf içinde gerçekleştirdikleri matematik öğretimlerinin de geliştirilebilir olduğunu kanıtlamıştır. Dolayısıyla öğretmenlerin kullandıkları temsil kullanımlarını geliştirmede diğer bir ifadeyle mesleki gelişimlerini desteklemede bu çalışma kapsamında kullanılan etkinliklerin mesleki gelişim çalışmalarında kullanılabilecek araçlara örnekler sunduğu söylenebilir.

Bir sonraki bölümde araştırmanın sonuçları göz önünde bulundurularak verilmiş öneriler yer almaktadır. 


\section{Öneriler}

Öğretmen eğitiminin sadece hizmet öncesi değil hizmet içinde de devam etmesi bir gerekliktir. Bu gereklilikten yola çıkılarak gerçekleştirilen bu çalışma sonunda öğretmenlerin belli bileşenler bağlamında gelişim ve değişim gösterdikleri görülmüştür. Bu değişim ve gelişim sadece öğretmenlerin öğretim bilgilerinde değil aynı zamanda direnç gösterdikleri bazı alışkanlıkların değişiminde de gözlenmiştir. $\mathrm{Bu}$ nedenle sadece üniversiteler, TÜBİTAK gibi kurumların bünyesinde gerçekleştirilen araştırmalar, tezler ya da projeler kapsamında değil, Milli Eğitim Bakanlığı tarafından planlı ve sürekli uygulanan alana özel mesleki gelişime yönelik çalışmaların yapılması önerilmektedir. Bu çalışma kapsamında öğretmenlerle birlikte hazırlanan TÖY'lerin mesleki gelişime yönelik bileşenlerin gelişiminde etkin bir rol oynadığı bu çalışma kapsamında görülmüştür. Ancak bu çalışmanın sadece altıncı sınıf cebir öğrenme alanında yer alan örüntüler ile sinırlandırıldığı dikkate alındığında, hem sınıf düzeyleri hem de öğrenme alanları bağlamında öğretmenlerin mesleki gelişimlerinde kullanılabilecek TÖY'ler geliştirilebilir. Aynı zamanda bunlar matematik dersi öğretim programlarına ve ögretmenler için hazırlanacak kılavuz kitaplara yansıtılabilir. Bu araştırma, öğretmenlerin matematik öğretim bilgilerini geliştirmenin matematik öğretimlerini de geliştirmeye yetmediği sonucunu ortaya koymuştur. Dolayısıyla mesleki gelişim programları sadece testlerle ölçülerek belirlenen öğretmen bilgisini geliştirmeye yönelik değil aynı zamanda gözlem yoluyla belirlenecek sınıf içi uygulamalarda kullandıkları yolları geliştirmeye yönelik planlanabilir.

\section{Kaynakça}

Ainsworth, S. (1999). The functions of multiple representations. Computers $\mathcal{E}$ Education, 33(2), 131-152. https://doi.org/10.1016/S0360-1315(99)00029-9

Akkoç, H., Özmantar, F., Bingölbali, E., Yavuz, İ., Baştürk, Ş., ve Demir, S. (2011). Matematik Öğretmen Adaylarına Teknolojiye Yönelik Pedagojik Alan Bilgisi Kazandırma Amaçlı Bir Program Geliştirme. Tübitak Projesi, 107K531, 20082011.

Arcavi, A., and Schoenfeld, A. H. (2008). Using the unfamiliar to problematize the familiar: The case of mathematics teacher in-service education. Canadian Journal of Science, Mathematics, and Technology Education, 8(3), 280-295. https:// doi.org/10.1080/14926150802315122

Ball, D. L., Thames, M. H., and Phelps, G. (2008). Content knowledge for teaching: What makes it special. Journal Of Teacher Education, 59(5), 389-407. https:/ / doi.org/10.1177/0022487108324554

Borko, H., Jacobs, J., Koellner, K., and Swackhamer, L. (2015). Mathematics professional development: Improving teaching using the problem-solving cycle and leadership preparation models. New York: Teachers College Press.

Bulut, D. B., Aygün, B., and İpek, A.S. (2018). Meaning of the Primary and Secondary School Students towards Equal Sign. Turkish Journal of Teacher Education, 7(1), 1-16.

Cai, J., and Hwang, S. (2002). Generalized and generative thinking in US and Chinese students' mathematical problem solving and problem posing. The Journal of Mathematical Behavior, 21(4), 401-421. https:/ / doi.org/10.1016/S0732-3123(02)00142-6 
Common Core State Standards. (2015). Common Core Standards Initiative. Retrieved from http://www.corestandards.org/.

Çelik, D., ve Sağlam-Arslan, A. (2012). Öğretmen adaylarının çoklu gösterimleri kullanma becerilerinin analizi. İlköğretim Online, 11(1), 239-250.

Çıkla, O. A., and Çakıroğlu, E. (2006). Seventh grade students' use of multiple representations in pattern related algebra tasks. Hacettepe Üniversitesi Eğitim Fakültesi Dergisi, 31(31), 13-24.

Dündar, S., ve Yılmaz, Y. (2015). Matematik öğretmen adayları hangi gösterim biçiminde daha başarılıdır? İntegral örneği. Turkish Journal of Computer and Mathematics Education, 6(3), 418-445. https:/ / doi.org/10.16949/turcomat.55314

Earnest, D., and Balti, A. A. (2008). Instructional strategies for teaching algebra in elementary school. Teaching Children Mathematics, 14(9), 518-522. https:// doi.org/10.5951/TCM.14.9.0518

Eroğlu, D., ve Tanışlı, D. (2015). Ortaokul matematik öğretmenlerinin temsil kullanımına ilişkin öğrenci ve öğretim stratejileri bilgileri. Necatibey Ĕğitim Fakültesi Elektronik Fen ve Matematik Eğitimi Dergisi, 9(1), 275-307. https://doi.org/10.17522/nefefmed.53039

Eroğlu, D., Camci, F., ve Tanışlı, D . (2019). Ortaokul altıncı sınıf öğrencilerinin kesir bilgilerinin yapılandırılmasına ilişkin tahmini öğrenme yol haritası: Bir öğretim tasarımı. Pamukkale Üniversitesi Eğitim Fakültesi Dergisi, 45, 116-143. https:/ / doi.org/10.9779/PUJE.2018.225

Even, R. (1998). Factors involved in linking representations of functions. The Journal of Mathematical Behavior, 17(1), 105-121. https:/ / doi.org/10.1016/S07323123(99)80063-7

Even, R. (1990). Subject matter knowledge for teaching and the case of functions. Educational Studies in Mathematics, 21(6), 521-544. https:// doi.org/10.1007/BF00315943

Fishman, B. J., Marx, R. W., Best, S., and Tal, R. T. (2003). Linking teacher and student learning to improve professional development in systemic reform. Teaching and teacher education, 19(6), 643-658. https:// doi.org/10.1016/S0742051X(03)00059-3

Gagatsis, A., and Shiakalli, M. (2004). Ability to translate from one representation of the concept of function to another and mathematical problem solving. Educational psychology, 24(5), 645-657. https:// doi.org/10.1080/0144341042000262953

Gökkurt, B., ve Soylu, Y. (2016). Ortaokul matematik öğretmenlerinin pedagojik alan bilgilerinin bazı bileşenler açısından incelenmesi: koni örneği. İlköğretim Online, 15(3), 946-973. https:/ / doi.org/10.17051/io.2016.14548

Heinze, A., Star, J. R., and Verschaffel, L. (2009). Flexible and adaptive use of strategies and representations in mathematics education. ZDM Mathematics Education, 41， 535-540. https://doi.org/10.1007/s11858-009-0214-4

Higgins, J., and Parsons, R. (2009). A successful professional development model in mathematics: A system-wide New Zealand case. Journal Of Teacher Education, 60(3), 231-242. https://doi.org/10.1177/0022487109336894 
İncikabı, S., and Biber, A. Ç. (2018). Transitions Among The Representations in The Middle School Mathematics Textbooks. Kastamonu Education Journal, 26(3), 729-740. https:/ / doi.org/10.24106/kefdergi.415690

İncikabi, S. (2017). Çoklu temsiller ve matematik ögretimi: ders kitaplari üzerine bir inceleme. Cumhuriyet International Journal of Education, 6(1), 66. https:// doi.org/10.30703/cije.321438

İpek, A. S., and Okumuş, S. (2012). The representations of pre-service elementary mathematics teachers used in solving mathematical problems. Gaziantep University Journal of Social Sciences, 11(3), 681-700.

Karsenty, R. (2018). Professional development of mathematics teachers: Through the lens of the camera. In G. Kaiser, H. Forgasz, M. Graven, A. Kuzniak, E. Simmt, and B. Xu (Eds.), Invited lectures from the 13th international congress on mathematical education (pp. 269-288). Hamburg: Springer. https:/ / doi.org/10.1007/9783319-72170-5_16

Leikin, R. (2006). Learning by teaching: The case of Sieve of Eratosthenes and one elementary school teacher. In R. Zazkis and S. Campbell (Eds.), Number theory in mathematics education: Perspectives and prospects (pp.115-140). Mahwah, NJ: Erlbaum.

Lesh, R., Post, T. R., and Behr, M. (1987). Dienes revisited: Multiple embodiments in computer environments. In I. Wirsup and R. Streit (Eds.), Development in school mathematics education around the world (pp. 647-680). Reston, VA: National Council of Teachers of Mathematics.

Mitchell, R., Charalambous, C. Y., and Hill, H. C. (2014). Examining the task and knowledge demands needed to teach with representations. Journal of Mathematics Teacher Education, 17(1), 37-60. https://doi.org/10.1007/s10857013-9253-4

Moon, K., Brenner, M. E., Jacob, B., and Okamoto, Y. (2013). Prospective secondary mathematics teachers' understanding and cognitive difficulties in making connections among representations. Mathematical Thinking and Learning, 15(3), 201-227. https:/ / doi.org/10.1080/10986065.2013.794322

Nathan, M. J., and Knuth, E. J. (2003). A study of whole classroom mathematical discourse and teacher change. Cognition and instruction, 21(2), 175-207. https:// doi.org/10.1207/S1532690XCI2102_03

National Council of Teachers of Mathematics. (2014). Principles to actions: ensuring mathematical success for all. Reston, VA.

Patton, M. Q. (2014). Nitel araştırmada çeşitlilik, kuramsal yönelimler. M. Bütün ve S. B. Beşir (Çev. Ed.). Nitel araştırma ve değerlendirme yöntemleri içinde (ss. 75142). Ankara: Pegem Akademi Yayıncilık.

Powell, A.B., Francisco, J.M., and Maher, C.A. (2003) An analytical model for studying the development of learners mathematical ideas and reasoning using videotape data. The Journal of Mathematical Behavior, 4(22), 405-435. https:// doi.org/10.1016/j.jmathb.2003.09.002

Schwarts, G., and Karsenty, R. (2020). “Can this happen only in Japan?": mathematics teachers reflect on a videotaped lesson in a cross-cultural context. Journal of Mathematics Teacher Education, 23(6), 527-554. https://doi.org/10.1007/s10857019-09438-z 
Seidel, T., Stürmer, K., Blomberg, G., Kobarg, M., and Schwindt, K. (2011). Teacher learning from analysis of videotaped classroom situations: Does it make a difference whether teachers observe their own teaching or that of others? Teaching and Teacher Education, 27(2), 259-267. doi:10.1016/j.tate.2010.08.009.

Sherin, M. G., and van Es, E. A. (2009). Effects of video club participation on teachers' professional vision. Journal of Teacher Education, 60(1), 20-37. https:// doi.org/10.1177/0022487108328155

Shulman, L. S. (1986). Those who understand: Knowledge growth in teaching. Educational researcher, 15(2), 4-14. https:// doi.org/10.3102/0013189X015002004

Simon, M. A. (1995). Reconstructing mathematics pedagogy from a constructivist perspective. Journal for Research in Mathematics Education, 26, 114-145. https:// doi.org/10.5951/jresematheduc.26.2.0114

Simon, M. (2000). Research on mathematics teacher development: The teacher development experiment. In A. Kelly, and R. Lesh (Eds.), Handbook of research design in mathematics and science education (pp. 335-359). Hillsdale, NJ: Lawrence Erlbaum Associates Publishers.

Simon, M. A. (2006). Key developmental understandings in mathematics: A direction for investigating and establishing learning goals. Mathematical thinking and learning, 8(4), 359-371. https://doi.org/10.1207/s15327833mt10804_1

Simon, M. (2014). Hypothetical learning trajectories in mathematics education. Encyclopedia of mathematics education, 272-275. https:/ / doi.org/10.1007/978-94-007-4978-8_72

Stein, M. K., and Bovalino, J. W. (2001). Manipulatives: One piece of the puzzle. Mathematics Teaching in the Middle School, 6(6), 356-359. https:// doi.org/10.5951/MTMS.6.6.0356

Şimsek, N., and Boz, N. (2016). Analysis of Pedagogical Content Knowledge Studies in the Context of Mathematics Education in Turkey: A Meta-Synthesis Study. Educational Sciences: Theory and Practice, 16(3), 799-826.

Tanışlı, D. (2013). İlköğretim matematik öğretmeni adaylarının pedagojik alan bilgisi bağlamında sorgulama becerileri ve öğrenci bilgileri. Ĕ̆itim ve Bilim, 38(169), 80-95.

Tataroglu Tasdan, B., Erduran, A., and Çelik, A. (2015). A daunting task for preservice mathematics teachers: developing students' mathematical thinking. Educational Research and Reviews, 10(16), 2276-2289.

Türnüklü, E. B. (2005). The relationship between pedagogical and mathematical content knowledge of pre-service mathematics teachers. Eurasian Journal of Educational Research, 21, 234-247.

Yayla, G., ve Özsevgeç, T. (2015). Ortaokul öğrencilerinin grafik becerilerinin incelenmesi: Çizgi grafikleri oluşturma ve yorumlama. Kastamonu Ĕ̆itim Dergisi, 23(3), 1381-1400.

Yıldırım, Z., ve Albayrak, M. (2016). Ortaokul Öğrencilerinin Farklı Temsil Biçimlerine Göre Doğrusal İlişki Konusunu Anlama Düzeylerinin İncelenmesi. Adnan Menderes Üniversitesi Ĕ̆itim Fakültesi Ĕ̆itim Bilimleri Dergisi, 7(2), 11-26. 


\section{Summary}

\section{Introduction}

Teacher's knowledge of representation and relations between representations in order to be able to teach effective mathematics are important. However, in addition to teacher's knowledge of representations, which is important for effective mathematics teaching and student' learning, the way to apply this knowledge is also important when teaching mathematics. "Mathematics teaching cycle" is the basis for this study. In this research, the "Hypothetical learning trajectories" and "teacher knowledge" components of this framework are discussed. In the context of teacher knowledge, the focus is on "teacher knowledge about mathematical activity and representations". Using the mathematics teaching cycle, hypothetical learning trajectories were designed in this research (teaching objectives and activities were prepared in collaboration with teachers and researchers). In this way, the purpose was to improve the teachers' use of representation during the implementation of these learning trajectories. During the implementation of teaching activities, there are two situations expected from teachers:

1. To guide students to use representations (table, symbolic, and verbal) based on students' thinking during the activities and to enable students to create their own representation,

2. To organize students' thinking about the representations and to guide the students to establish a relationship between the representations.

The ways that teachers use mathematical representations in teaching are important in order to make students successful. The national literature review revealed that there are few studies examining teachers' representation knowledge and related practices. In addition, the research in Turkey carried out by teachers and often prospective teachers is based on the pedagogical content knowledge, mathematical teaching knowledge, student knowledge, and curriculum knowledge which are identified with descriptive ways. This research is also a professional development study and provides information on how teachers' classroom practices were improved. Based on these requirements, this research investigated how the representations used by teachers can be integrated into teaching based on student thinking. After that, this study develop teachers' teaching on how to guide students for the use of representation based on students' thinking, and how to guide students in building relationships between representations by organizing their emerging thinking on representations. This research is also considered important in terms of providing information on which professional development practices this development can be accomplished and how teachers can use representations in their teaching based on hypothetical learning trajectories. The purpose of the research is to examine the development of elementary mathematics teachers' use of multiple representation and translations between representations throughout the implementations of hypothetical learning trajectories.

\section{Methodology}

This research is a "teacher development experiment" and two middle school mathematics teachers participated in this research. Teacher development experiment as a research method and teacher development model were adopted. It has two parts 
used together that are (1) teaching experiment and (2) case study methods. This research took place over a period of 10 weeks. The research was conducted in 3 different stages. In the first stage, hypothetical learning trajectories were prepared covering all the objectives in the domain of algebra in the sixth grade and assuming the effective use of representations during teaching. At this stage, professional development activities were prepared for the teaching experiments which is conducted every week with the teachers. In the second stage, one of the experts carried out a teaching experiment with two teachers. Following the professional development activity, teaching activities were designed with teachers in accordance with the hypothetical learning trajectories. In the third stage, teachers implemented teaching activities based on hypothetical learning trajectories in their classrooms. Teachers taught 5 lesson hours in the first five weeks of this phase and 2 lesson hours in the last four weeks.

In this research, two different main data were used to reveal the development of teachers in the use of representation within their teaching: (1) course videos taken during the teaching of teachers, (2) videos taken during professional development meetings with teachers. In this study, 64 hours of video recordings taken in the case study and 40 hours of video recordings taken in teaching experiments were analyzed. After the completion of the three-phase process in the teacher development experiment, the videos defined as data were watched again and the sections presented to the validity-reliability committee were translated. Following the completion of the translations, the dialogues were coded. In the coding phase, separate codes were assigned for each teacher. After coding all the data, a storyline was created to reveal the development of teachers. The storyline included 17 activities selected from 64 lesson hours, which is showing the development of teachers.

\section{Results}

Results of this research revealed that teachers guide students to use representation based on students' thinking, to enable students to form their own representations, and to guide students in establishing relationships by organizing their emerging thinking about representations. While teachers did not use representations in depth at the beginning, their use of representations changed conceptually towards the end of the research. In addition, at the end of the research, they used multiple representations as a tool based on student thinking and made the relationships between these representations. While there was no relationship between representations they used at the beginning of the research, they included the relations between the representations towards the end of the research. They also guided students to create different forms of representation and guided students to relate representations.

\section{Recommendations}

In this study, it was revealed that the hypothetical learning trajectories designed with teachers play an active role in the development of components for professional development. Therefore, the Ministry of National Education should plan and implement professional development programs for teachers. These professional development programs should be for not only improving teacher knowledge, which is determined by measuring with tests, but also improving the ways they use in classroom practices to be determined through observation. Given that, teachers' 
awareness of their own learning affects their students' beliefs about how they learn; teachers can create their own learning environments they can learn with their colleagues. Finally, professional development programs should be planned to change teachers' beliefs about learning and teaching.

\section{Araştırmanın Etik İzinleri}

Yapılan bu çalışmada "Yükseköğretim Kurumları Bilimsel Araştırma ve Yayın Etiği Yönergesi" kapsamında uyulması belirtilen tüm kurallara uyulmuştur. Yönergenin ikinci bölümü olan "Bilimsel Araştırma ve Yayın Etiğine Aykırı Eylemler" başlı̆̆ı altında belirtilen eylemlerden hiçbiri gerçekleştirilmemiştir.

Etik kurul izin bilgileri

Etik değerlendirmeyi yapan kurul ad $1=$ Anadolu Üniversitesi Rektörlüğ ü Etik Kurulu Etik değerlendirme kararının tarihi=28.05.2014

Etik değerlendirme belgesi sayı numarası= 2/10 sayılı etik kurul kararı

\section{Authors' Biodata/ Yazar Bilgileri}

Deniz EROĞLU Burdur Mehmet Akif Ersoy Üniversitesi, Eğitim Fakültesi, Matematik Eğitimi Anabilim Dalında Öğretim Üyesi olarak görev yapmaktadır.

Deniz Eroglu works at Burdur Mehmet Akif Ersoy University, Faculty of Education, Department of Mathematics Education as an Assistant Professor.

Dilek TANIŞLI Anadolu Üniversitesi, Eğitim Fakültesi, Matematik Eğitimi Anabilim Dalında Öğretim Üyesi olarak görev yapmaktadır.

Dilek Tanışlı works at Anadolu University, Faculty of Education, Department of Mathematics Education as a Professor. 